\title{
Semântica e pragmática: duas formas de descrever e explicar os fenômenos da significação
}

\author{
Rodolfo llari \\ Universidade Estadual de Campinas
}

\section{Abstract}

The boundaries between Semantics and Pragmatics still deserve to be investigated, since they remain unclear for many linguists, and since the word "pragmatics" has quite often been used among Brazilian linguists in an unscientific, rhetorical way, to enhance the importance of some approaches to meaning and interpretation.

This paper claims that a theoretically sound boundary can be drawn between semantical and pragmatical approaches if we look at the way they deliver interpretations. Semantic interpretations are typically the result of some kind of calculus, whereas pragmatic interpretations are typically the result of some working out where no calculus intervenes, rather a highly specific solution is sought in order to integrate some unexpected fact into a coherent story. Thus defined, Semantics and Pragmatics can be referred to as deduction and abduction, respectively.

In the light of the distinction just described, I revisit some of the phenomena that were pointed out in the last decades as best examples of the pragmatic functioning of natural language. I argue that presupposition, deixis and speech acts, highly predictable from lexicon and grammar, are semantical in nature; on the contrary, implicature, since it depends on abductive thinking and it is not predictable from linguistic form, is described as a pragmatic phenomenon par excellence. 


\section{INTRODUÇÃO}

o longo deste escrito, procuro explicitar o critério que venho
usando para traçar um limite. Trata-se do limite, a meu ver
necessário, mas nem sempre claro, que separa as duas principais disciplinas lingüísticas que tratam da significação: a semântica e a pragmática. Entendendo que essas duas disciplinas dizem respeito aos mesmos objetos, mas se caracterizam por modos de fazer diferentes, procuro apontar alguns exemplos de análises que ilustram sua especificidade.

Nessa busca de exemplos, fui levado a considerar um certo número de fenômenos (como a dêixis, a pressuposição, os atos de fala, as implicaturas conversacionais), a propósito dos quais já se pensou que um tratamento semântico pouco ou nada teria a dizer e que seriam, nesse sentido, essencialmente pragmáticos. Defendo que uma análise semântica é sempre o primeiro passo necessário, e que freqüentemente ela basta para dar conta dos principais problemas encontrados.

A posição que assim adoto contraria uma tendência, que foi majoritária na lingüística brasileira nos últimos 30 anos, e que consistiu em buscar uma explicação pragmática para muitos fatos de linguagem dignos de nota, sem avaliar previamente as possibilidades de uma boa explicação semântica; sugiro que essa tendência resultava de uma certa desinformação a respeito dos avanços da semântica e contribuiu fortemente para que os estudos da significação, neste país, continuassem a ser praticados de forma intuitiva, informal e pouco explícita. Defendo que minha posição tem vantagens em relação à tendência dominante, a primeira das quais é a de valorizar a análise pragmática, mostrando que, em certos casos, ela é efetivamente indispensável, e que, nesses casos, ela se 
faz como uma prática de abdução (a tendência oposta banalizava a pragmática dando a entender que "tudo é pragmático").

Por tudo aquilo que acabo de dizer, o texto que segue é antes de mais nada a defesa de um ponto de vista, isto é, um ensaio. É importante que o leitor tenha em mente esse caráter de ensaio porque, como não poderia deixar de ser, o texto contém numerosas referências a autores e fenômenos que tiveram grande importância histórica para o desenvolvimento da semântica e da pragmática como disciplinas independentes, o que poderia sugerir que ele deve ser lido como uma retrospectiva dos estudos semânticos, ou um balanço de fenômenos de significação interessantes. Essas não são leituras que eu espero, por duas razões principais: 1) uma retrospectiva precisaria ser exaustiva, ao passo que são inúmeros os autores e escolas sobre os quais o presente trabalho silencia e que, ainda assim, tiveram um papel historicamente importante para levar ao tipo de estudo da significação que se faz hoje ${ }^{1}$; 2) uma introdução sobre fatos da significação precisaria definir e caracterizar com alguma precisão os vários fenômenos estudados, ao passo que o texto dá de barato que o leitor já se defrontou com eles em algum momento, e consegue reconhecê-los sem dificuldade, bastando para isso a referência a alguns exemplos clássicos ${ }^{2}$.

As palavras Semântica e Pragmática aparecem, junto com Sintática, em MORRIS (1933), para identificar três pontos de vista distintos que podem orientar o estudo de uma linguagem. Ao olhar para uma linguagem qualquer, podemos querer inventariar as expressões simples que lhe são próprias e estabelecer como se combinam para formar expressões complexas: estaremos analisando aspectos de sua sintaxe. Além da combinatória possível das expressões, isto é, das relações que os sinais mantêm entre si, podemos querer considerar as relações que eles mantêm com os objetos e com as situações do mundo: estaremos estudando esses mesmos sinais semanticamente. Podemos, por fim, querer incluir em 
nosso estudo mais um fator de complexidade: os interlocutores e a interação entre os interlocutores: estaremos adotando uma perspectiva pragmática.

Essa tripartição se aplica em princípio a qualquer sistema semiótico e pode ser facilmente exemplificada em situações corriqueiras envolvendo outras linguagens, além das verbais: suponhamos que, durante uma partida de buraco, um dos participantes baixe uma trinca de seis. No contexto da partida, alguém que observa o jogo (1) conclui que essa jogada foi uma maneira de bloquear a última chance de canastra do adversário; (2) constata que, independentemente das consequências que a jogada terá para o desenvolvimento da partida, o jogador fez quinze pontos; e verifica que a trinca foi aceita como válida enquanto combinação de cartas "baixadas" porque, pelas regras do jogo, é uma combinação permitida. A primeira observação é pragmática, a segunda semântica e a terceira sintática.

Imagine-se, por outro lado, que vimos escrita a seguinte frase, num outdoorà beira da estrada que estamos percorrendo de carro:

(1) Benvindo à Terra do Gado. Sessenta por cento dos caminhões desta região é Ford:

Afirmar que a frase é bem formada (por exemplo, porque o sujeito que exprime percentagem leva o verbo para o singular) é fazer sintaxe; observar que, em função do lugar em que o outdoor se localiza, "esta região" significa o Triângulo Mineiro, ou decidir em que condições é correta a informação prestada pelo outdoor, é fazer semântica; perceber que a mensagem visa ao efeito propagandístico de promover uma certa marca de caminhões é fazer pragmática.

Passados mais de cinqüenta anos desde sua formulação inicial, a tripartição de Morris continua válida como orientação, mas tem que ser referida a uma prática de investigação em que são comuns as áreas de sombra e superposição. Avulsos do contexto em que foram inicialmente propostos e aplicados a uma série de linhas de investigação em que Morris não tinha provavelmente pensado, os 
três termos precisam assumir sentidos ao mesmo tempo mais amplos e mais vagos, para manter sua utilidade.

Assim, para exemplificar um dos tantos problemas que se deparam hoje a quem queira aplicar a tripartição de Morris, parece inevitável incluir na semântica (e não na sintaxe) todos os estudos lexicológicos, apesar de que esses estudos, sobretudo na tradição corrente dos dicionários monolíngues, relacionam as expressões a outras expressões, descartando por opção as informações "enciclopédicas" - que mais imediatamente parecem caracterizar-se como informações sobre o mundo; a menos que a relação com os denotata seja recuperada de outra forma, é evidente a contradição entre o uso real e a definição.

Outros problemas surgem quando se questiona a dependência recíproca dos três enfoques: tais como Morris as representa, as três disciplinas dispõem-se numa ordem precisa de abrangência, em que a pragmática, que trata das relações entre sinais, denotata e locutores, inclui, por assim dizer, a semântica, que "apenas" relaciona sinais e denotata, e esta inclui por sua vez a sintaxe, que se limita às relações entre sinais. Ora, já ocorreu com freqüência que, no decorrer de uma análise empírica, os investigadores se vissem defrontados com fenômenos que, aparentemente localizados na área de fatos coberta por uma das duas disciplinas "menos abrangentes", só podiam receber uma formulação realmente adequada no nível de abrangência superior; muitos pesquisadores foram levados desse modo a reivindicar ao invés de uma representação hierárquica, uma interpenetração dos vários níveis. ${ }^{3}$

A maneira como a estrutura da sentença foi descrita pela recente Escola de Praga (por exemplo em DANES, 1966, onde se distinguem uma sintaxe que estrutura unidades morfológicas, uma sintaxe que estrutura sentidos e uma sintaxe que estrutura unidades informativas relevantes para a eficácia da comunicação) poderia num primeiro momento ser considerada como uma ilustração perfeita da teoria de Morris, mas de fato não o é, porque se recusa a hierarquizar, e algumas de suas noções centrais - por exemplo, a de marcado e 
não-marcado - visam a distinguir diferentes formas de mapeamento para estruturas lingüísticas apontadas por análises independentes, que tratam de objetos teóricos distintos.

Dadas essas dificuldades de aplicação, a tripartição de Morris será utilizada, na seqüência deste texto, não pelas tarefas que atribui às três disciplinas, mas por conter uma sugestão que, embora não seja de todo óbvia, me parece real: a da progressiva complexidade dos instrumentos de que precisam dotar-se as três disciplinas que distingue. Ao passar do ponto de vista sintático para o semântico e deste para o pragmático, não só se amplia a quantidade de fatos estudados, mas incorporam-se fatos de natureza diferente, exigindose em conseqüência uma aparelhagem metodológica mais poderosa e complexa; em outras palavras, os recursos descritivos que resultam eficazes nas disciplinas menos abrangentes revelam-se insuficientes tão logo se adota a perspectiva mais rica. No que diz respeito especificamente à pragmática, a necessidade de reconhecê-la como uma disciplina autônoma justifica-se principalmente pela resistência que uma série de aspectos da significação opõem a um tratamento estritamente semântico.

Esse enfoque me parece produtivo mesmo sabendo que ele leva a encarar a história da pragmática como uma história pouco integrada, que se construiu pelo acumular-se de problemas que por assim dizer "sobravam" dos tratamentos semânticos mais exigentes e mais bem sucedidos. Um dos desafios que se apresentam a quem procura traçar essa história é mostrar que os problemas em questão têm características comuns, que podem ser tomadas como contraprova de sua natureza pragmática.

$\mathrm{Na}$ medida em que reservo à pragmática um repertório de problemas em que os métodos semânticos se demonstram inadequados, meu exame do limite entre as duas disciplinas só poderia começar por uma definição das tarefas da semântica. Aqui, a existência de uma pluralidade de orientações poderia, à primeira vista, ser um motivo de desnorteamento; para evitar esse desnorteamento, definirei as tarefas da semântica a partir da orientação que 
me parece mais representativa, a da chamada "semântica das condições de verdade". Não procurarei justificar essa escolha: no essencial, ela leva a um programa de pesquisa mínimo que é pressuposto por todas as teorias semânticas intuitivamente válidas que conheço. Em outros textos como este discuto questões que são relevantes, ainda que de maneira indireta, para justificar minha escolha. ${ }^{4}$

\section{O PROGRAMA DA SEMÂNTICA}

A semântica passou a definir seu programa como o estudo das "condições de verdade" dos enunciados das línguas naturais, influenciada pelas idéias que o lógico e matemático polonês Alfred Tarski lançou, na década de 40, sobre a interpretação dos enunciados da matemática.

Escrevendo numa época em que se discutia acaloradamente sobre a natureza da verdade, tentando precisar o conteúdo intuitivo da noção (debatia-se, por exemplo, se a verdade deveria ser definida como correspondência dos enunciados com os fatos ou como coerência dos enunciados entre si, se a apreensão da verdade deveria ser intuitiva ou racional, etc.) Tarski interveio no debate modificando radicalmente os termos do mesmo. Ao invés de propor ou avaliar novas hipóteses psicológicas, Tarski enunciou uma exigência "mínima", que qualquer teoria da verdade precisaria ser capaz de satisfazer, independentemente do modo como definisse "verdade": toda teoria da verdade, para ser adequada, deveria ser capaz de derivar, para cada uma das sentenças S de uma língua dada, um teorema do tipo:

(2) (Convenção T)

"S" é verdadeira se e somente se $p$,

onde " $S$ " é o nome da sentença $S$ na língua adotada como metalinguagem, e $p$ é um enunciado da metalinguagem em que se definem as condições em que " $S$ " é verdadeira. 
Imagine-se para maior concretude que queiramos explicar em português em que condições é verdadeira a sentença francesa

(3) Deux et deux font quatre.

Estaremos nesse caso tomando o português como metalinguagem, e o francês como linguagem objeto. A maneira correta, conforme (2), de formular as condições de verdade de (3) é

(4) "Deux et deux font quatre" é verdadeira se e somente se dois e dois são quatro.

onde $\quad S=$ Deux et deux font quatre e

$\mathrm{p}=$ dois e dois são quatro.

Utilizando as aspas na função que elas costumam desempenhar nos textos de lógica, indica-se que o sujeito gramatical de (4), "deux et deux font quatre"; nomeia um enunciado da linguagem objeto; ao mesmo tempo (4) coloca esse enunciado em correspondência com um outro enunciado da metalinguagem, "dois e dois são quatro", que é verdadeiro exatamente nas mesmas condições.

A exigência que Tarski fez às teorias da verdade não contribui em nada para uma melhor compreensão do que seja a verdade em termos psicológicos, e é, nesse sentido, profundamente frustrante. A impressão de frustração tende a aumentar quando a proposta de Tarski é transferida sem maiores explicações às línguas naturais (uma possibilidade que Tarski recusava) e quando uma mesma língua natural passa a funcionar simultaneamente como linguagem e metalinguagem. Realmente, enunciados como

(5) "Dois e dois são quatro" é verdadeira se e somente se dois e dois são quatro

"A neve é branca" é verdadeira se e somente se a neve é branca

soam a uma primeira leitura como totalmente desinformativos, e a idéia de construir algum aparato teórico que os produza pode parecer altamente ociosa. Essas impressões resultam de uma compreensão caricatural da proposta de Tarski. Para corrigi-las, considere-se mais atentamente o que está em jogo em (2). 
(a) Em primeiro lugar, essa fórmula estabelece a distinção entre linguagem e metalinguagem, com um grau de rigor que nem sempre se encontra nos trabalhos de semântica. Tarski preocupou-se muito com essa distinção, lembrando que, se ela for apagada se incorporam automaticamente em qualquer discurso linguístico contradições insuperáveis, que são variantes do paradoxo do mentiroso ("Todo cretense é mentiroso e eu sou cretense"), e que podem ser exemplificadas pelas contradições que afetam (6):

(6) A sentença que neste texto se identifica pelo número (6) é falsa.

Segundo Tarski, a possibilidade de falar das sentenças de uma língua nessa mesma língua, quebrando os limites entre linguagem e metalinguagem é um traço inerente às línguas naturais, que as torna internamente contraditórias. Por isso, Tarski restringia seu método ao discurso matemático, e imaginava que, mesmo para este, seria preciso conceber uma hierarquia de linguagens com poder expressivo cada vez maior, de modo que as mais poderosas (ou expressivas) funcionassem como metalinguagem para as menos expressivas. Contrariando o pessimismo de Tarski, muitos autores que trabalharam sob sua influência aplicaram sua teoria da verdade às línguas naturais, para tratar pelo menos dos enunciados que não apresentam problemas de auto-referencialidade.

Nessa aplicação, a distinção entre linguagem e metalinguagem permite entender em que sentido aqueles enunciados são informativos: "Deux et deux font quatre", "Dois e dois são quatro" ou "A neve é branca", são nomes metalingüísticos de uma sentença da linguagemobjeto, e como tais designam uma expressão lingüística que se pretende explicar; a explicação que se espera consiste em pronunciar uma sentença que tem idênticas condições de verdade numa língua que usamos e compreendemos. Esse procedimento nos dá, à sua maneira, uma tradução, no sentido em que uma tradução vale por um desvendamento. Obviamente, os exemplos mais convincentes da aplicação do método de Tarski às línguas naturais são aqueles em que a língua-objeto é inteiramente desconhecida, como (7), em que 
se formulam as condições de verdade para uma sentença do checo, uma língua provavelmente desconhecida para a maioria dos leitores:

(7) "Nemci mluvívají spatne cesky " é verdadeira se e somente se a maioria dos alemães fala mal o tcheco.

Mas em princípio o procedimento é o mesmo quando as duas partes do esquema são preenchidas por expressões de duas línguas conhecidas ou mesmo de uma única língua conhecida. Para todos os efeitos, as sentenças de (5) não deveriam parecer mais absurdas do que certas definições de dicionário, por exemplo, a que explica "edema" como "inchaço".

(b) Uma outra maneira de explicar o que se passa no esquema (2) consiste em reconhecer que, mediante o operador

“... é verdadeira se e somente se ...",

se realiza a transferência de uma quantidade de informações do domínio da citação e das aspas (domínio em que que apenas aludimos a uma expressão lingüística) para o domínio do uso: o papel do esquema (2) caracteriza-se assim como o de "extrair do domínio da citação", um papel para o qual na semântica anglo-saxônica de ascendência tarskiana se cunhou a expressão "disquotational". Como veremos, essa abordagem "disquotational" pode ser aplicada a unidades lingüísticas menores ou maiores que a sentença, e isso abre uma perspectiva em que cada expressão faz uma contribuição específica às condições de verdade do todo. Analisar essas contribuições pode ser por sua vez um programa semanticamente relevante, se não um programa semântico completo.

(c) Finalmente, mas não menos importante, lembre-se que a condição de adequação estabelecida por Tarski diz respeito a teorias da verdade e exige que um enunciado verdadeiro construído segundo o molde (2) seja proposto para cada uma das sentenças da língua objeto (na realidade a exigência de Tarski é ainda mais forte: os enunciados que especificam as condições de verdade devem ser produzidos como teoremas de um sistema axiomático). Ora, Tarski 
sabia que as línguas que apresentam algum interesse são infinitas quanto ao número de sentenças que comportam. Essa infinitude propõe um desafio ao pesquisador, porque as condições de verdade de suas sentenças não podem ser estabelecidas mediante uma lista fechada de enunciados do tipo (2), mas Tarski mostrou que é possível enunciar as condições de verdade para todas as sentenças de uma língua infinita considerando os processos que intervêm em sua construção.

Uma demonstração satisfatória - ao mesmo tempo simples e convincente - de como se pode construir um mecanismo formal capaz de fornecer uma definição de verdade para fórmulas de uma linguagem infinita pode ser encontrada no tratamento semântico que os lógicos têm dado ao segmento mais simples das linguagens de primeira ordem, o cálculo sentencial. Como o nome indica, o cálculo sentencial trata de linguagens cujas unidades elementares são sentenças, passíveis de combinar-se entre si mediante um número limitado de operações sintáticas que formam novas sentenças. Os manuais apresentam geralmente cinco dessas operações: a negação, a conjunção, a disjunção e a implicação e a equivalência, lembrando entretanto que essas operações são interdefiníveis e que seria portanto possível reduzir seu número.

Para entender como a exigência de Tarski se aplica ao cálculo sentencial, é preciso lembrar duas características daquela linguagem: a) sua infinitude e b) seu caráter estritamente extensional. Recapitulemos essas duas características:

a) a aplicação das operações do cálculo sentencial que constroem sentenças é recursiva, de modo que essa linguagem é infinita (por exemplo, " $\rightarrow$ " aplica-se a expressões qualificadas como sentenças, como A e B, resultando em expressões como $[\mathrm{A} \rightarrow \mathrm{B}]$, que são por sua vez qualificadas como sentenças, e portanto podem entrar na composição de sentenças mais complexas como $[\mathrm{B} \rightarrow[\mathrm{A} \rightarrow \mathrm{B}]]$, e assim sucessivamente);

b) de todas as características semanticamente relevantes que se poderiam atribuir a uma sentença, a única a que o cálculo 
sentencial é sensível é o seu valor de verdade; as diferentes operações do cálculo sentencial e os conectivos que as expressam são veri-funcionais, isto é, são definidos como maneiras específicas de correlacionar o valor de verdade das expressões complexas que formam ao valor de verdade das expressões componentes (para expressar essas diferentes correlações, os manuais recorrem habitualmente às chamadas "tabelas de verdade"); isso possibilita o cálculo do valor de verdade das expressões complexas, uma vez definido o valor de verdade das expressões componentes.

Usualmente formuladas como em (8),

(8) Se $\xi$ for uma sentença da forma $[\psi \rightarrow \varphi]$, $\xi$ é verdadeira se e somente se $\varphi$ for verdadeira ou $\psi$ for falsa,

as regras semânticas para os conectivos do cálculo sentencial submetem o conectivo a um procedimento de "dis-quotation" e de "tradução": na porção direita da fórmula, em vez de " $\rightarrow$ ”, encontramos apenas expressões da linguagem corrente, reconstituindo de maneira compreensível para um falante nativo de português as condições de verdade da fórmula complexa, que ficam, assim, completamente determinadas pelos valores de verdade das sentenças componentes.

Dadas as características do cálculo sentencial, qualquer de suas expressões, independentemente da complexidade que apresenta, pode ter seu valor de verdade calculado num número finito de passos, a cada um dos quais uma ocorrência de conectivo estará sendo "extraída das aspas" e "traduzida". Isto é possível porque a semântica é construída em paralelo a uma sintaxe recursiva (a cada regra sintática corresponde uma regra semântica) tornando-se, ela própria, recursiva.

Apesar de infinito, o cálculo sentencial fornece uma representação muito grosseira do funcionamento semântico das línguas naturais. Assim, para criar uma disposição favorável à aplicação do método de Tarski na análise das línguas naturais, teve um peso muito maior sua aplicação à semântica do cálculo de predicados e mais particularmente às chamadas "fórmulas quantificadas". Essa 
aplicação pode ser considerada paradigmática do tipo de semântica em que me parece importante investir; por isso, vou tratar dela um pouco mais extensamente nas próximas páginas. Para não sobrecarregar a exposição, evitarei contudo expor tecnicamente a sintaxe e a semântica do cálculo de predicados com quantificação; se porventura o leitor sentir a necessidade de referir-se a uma formulação mais técnica, poderá recorrer às apresentações feitas nos manuais de lógica e em muitos estudos de semântica linguística. ${ }^{5}$

A formalização dada por Tarski à semântica da quantificação responde simultaneamente a uma série de exigências que até então apareciam tão inextricavelmente relacionadas, quanto inconciliáveis.

A primeira dessas exigências era, obviamente, a de dar conta da contribuição que os quantificadores fazem às condições de verdade das sentenças, uma contribuição que Frege havia esclarecido de maneira magistral, ao mostrar que toda ocorrência de um quantificador se refere a uma (ou mais) lacuna(s) de um predicado, informando sobre o efeito, em termos de valor de verdade, que resulta de preencher essa lacuna mediante todos os objetos de que a linguagem pode falar. Os quantificadores "todos" e "pelo menos um", diria Frege, predicam globalmente sobre o quadro de preenchimentos possíveis das lacunas de predicado: são, nesse sentido, predicados de predicados.

Uma vez reconhecido que os quantificadores têm esse papel, que alguns autores descreveram pela metáfora do percurso, é imediato estabelecer uma distinção drástica entre a função semântica do sujeito gramatical de (9) e das sentenças (10a) e (10b), embora as três sentenças tenham a mesma distribuição gramatical e as mesmas propriedades "casuais":

(9) José brinca

(10) a. Toda criança brinca,

b. Alguma criança brinca

A diferença essencial é que a interpretação das sentenças de (10) está constitutivamente associada ao percurso de todo um domínio: (10) 
a. resultará verdadeira se o predidado "...brinca” for verdadeiro para todos os indivíduos do domínio; (10b) resultará verdadeira se o predicado "...brinca” for verdadeiro ao menos para um deles.

Entendamo-nos sobre a delimitação do domínio relevante. Pode-se aceitar a sugestão inerente à estrutura gramatical e entender que (10a) e (10b) falam do conjunto das crianças, mas tem sido muito mais usual associar a essas sentenças uma estrutura lógica que resulta verdadeira nas mesmas situações, e que trata a quantificação como sendo sempre relativa a todos os indivíduos de que a linguagem pode falar, o que resulta nas representações informais de (11), que têm por sua vez uma representação simbólica em (12):

(11) a. Aplica-se a todo indivíduo que (se ele for criança, ele brinca)

b. Aplica-se a algum indivíduo que (ele é criança e ele brinca)

(12) a. $\forall \mathrm{x}[\mathrm{C}(\mathrm{x}) \rightarrow \mathrm{B}(\mathrm{x})]$

b. $\exists \mathrm{x}[\mathrm{C}(\mathrm{x}) \& \mathrm{~B}(\mathrm{x})]$

Posso, com esses elementos, falar dos problemas que Tarski teve que solucionar, para aplicar seu método "disquotational" às sentenças quantificadas.

O problema de dar à semântica de (12a) e (12b) um tratamento estritamente composicional ${ }^{6}$ é o seguinte: o conectivo da implicação é veri-funcional, o que significa que o valor de verdade da expressão que ele produz precisa ser calculado a partir do valor de verdade das expressões componentes. Mas nem $\mathrm{C}(\mathrm{x})$ nem $\mathrm{B}(\mathrm{x})$ têm um valor de verdade definido. A possibilidade de calcular o valor da implicação a partir do valor das partes ficaria portanto descartada.

Frege já tinha considerado com atenção essas estruturas, opondo-as a outras como (13), cuja tradução lógica é (14):

(13) Se o sol já nasceu, então o céu está encoberto

(14) $\quad[\mathrm{N}(\mathrm{s}) \rightarrow \mathrm{E}(\mathrm{c})]$

No caso destas últimas, diz Frege, faz sentido determinar separadamente o valor de verdade do antecedente e do conseqüente da implicação e calcular a partir deles o valor de verdade da 
implicação como um todo; mas no caso de (12a), por exemplo, somos impedidos de fazê-lo pela existência de um "nexo" que vincula o antecedente e o conseqüente do condicional, de maneira indissolúvel. Não é difícil perceber que esse nexo, expresso pelo anafórico ele, nada mais é que uma ligação de variáveis. A generalização que se exprime em (12a) fica desmentida se pudermos apontar pelo menos um exemplo de criança que não brinca. (10a) será portanto verdadeira se, para cada um dos indivíduos de que a linguagem pode falar, a confirmação de sua condição de criança for acompanhada pela confirmação de sua disposição para brincar.

Somos assim levados a reconhecer em (12a), além do quantificador generalizante, toda uma expressão que tem forma sintática de sentença complexa e na qual as duas ocorrências de x aparecem ligadas, indicando que a característica de ser criança e a característica de brincar deverão ser verificadas, em sua conexão condicional, para cada um dos indivíduos de que fala a linguagem. A essa subparte de (12a) não se pode contudo atribuir um valor de verdade: semanticamente ela é uma estrutura aberta, um predicado, que exprime uma "propriedade complexa" que poderíamos expressar como segue: "...é tal que se...for criança, ...brinca”.

Tarski defrontou-se, pois, com o problema de dar a (12a) e (14) um tratamento semântico baseado na sintaxe dessas fórmulas e, portanto, essencialmente idêntico; paradoxalmente, esse tratamento precisaria levar em conta o caráter veri-funcional dos conectivos em contextos nos quais eles ligam proposições que não são nem verdadeiras nem falsas, mas abertas; precisaria ainda considerar o papel das variáveis que aparecem ligadas em (12a), que é o de aplicar aos diferentes indivíduos do universo de discurso propriedades "complexas" no sentido acima descrito.

A solução que ele propôs é ao mesmo tempo simples e elegante. $\mathrm{Na}$ impossibilidade de tratar em termos de verdade os constituintes encontrados para (12a) nos níveis mais baixos de estruturação daquela fórmula (os níveis que na figura a seguir ficaram abaixo da linha), Tarski aplica-lhes uma noção sucedânea - a de 
satisfação de uma fórmula aberta por uma seqüência de objetos que contribui para definir a verdade das sentenças quantificadas, mas desaparece tão logo realizou sua tarefa.
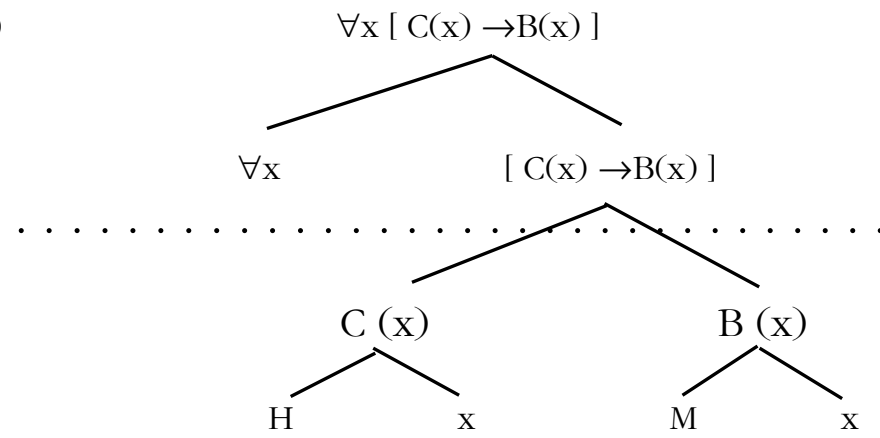

Examinemos passo a passo essa solução.

1. O primeiro passo consiste em ordenar as variáveis da língua, definindo uma função de atribuição, que associa um objeto do mundo a cada uma delas. Os objetos do mundo aparecem assim organizados em forma de uma seqüência (com eventuais repetições de objetos, mas sem lacunas: a cada variável corresponde um objeto, mas um mesmo objeto pode corresponder a duas ou mais variáveis. Obviamente, as atribuições possíveis crescem em progressão exponencial, dependendo do número de objetos do mundo).

2. As expressões $\mathrm{C}(\mathrm{x})$ e $\mathrm{B}(\mathrm{x})$, por consistirem em predicados, não são obviamente verdadeiras ou falsas em nenhum mundo, mas uma determinada seqüência de objetos pode satisfazê-las, se ela apresentar no lugar correspondente à variável x um objeto a que o predicado se aplica. As noções de satisfação e de atribuição fornecem, assim, um sucedâneo para a noção de verdade, para os níveis em que esse conceito não seria aplicável.

3. As fórmulas quantificadas remetem, como se viu acima, a uma operação de percurso, que é capturada na explicação de Tarski, pela possibilidade de passar de uma atribuição a outras, alterando o objeto que ocupa uma determinada posição. Essa busca de 
"variantes de uma atribuição" é crucial na formulação de regras semânticas para os quantificadores; assim diz-se habitualmente que

- $\forall \mathrm{x} F(\mathrm{x})$ é verdadeira se $\mathrm{F}(\mathrm{x})$ for verdadeira em todas as variantes que sejam iguais a uma atribuição tomada como ponto de partida, exceto no máximo quanto ao objeto que ela liga a $\mathrm{x}$;

$-\exists \mathrm{x} F(\mathrm{x})$ é verdadeira se $\mathrm{F}(\mathrm{x})$ for verdadeira em pelo menos uma variante que seja igual a uma atribuição tomada como ponto de partida, exceto no máximo quanto ao objeto que ela liga a $\mathrm{x}$.

Em sua aplicação prática, esse método consiste em adotar arbitrariamente uma atribuição qualquer (etapa 1 acima); os predicados das fórmulas abertas serão ou não safisfeitos por essa atribuição (etapa 2); a presença de quantificadores orienta no sentido de buscar as variantes de uma atribuição (etapa 3), e de trocar o conceito de satisfação pelo de verdade. Percebe-se que, por este método, o conceito de satisfação permite desenvolver uma semântica para as fórmulas abertas, acompanhando passo a passo sua construção sintática, e que ele é descartado no momento em que, no processo sintático de construção, a fórmula aberta é acoplada a um quantificador que a "fecha".

É possível mostrar que esse método surte os resultados desejados quando a sentença comporta duas ou mais ocorrências dos quantificadores todos e algum, como nestas sentenças de Chierchia:

(16) Todos os homens deram algum livro à mulher

(17) Algum livro, todos os homens deram à mulher.

Graças a essa solução para a semântica dos quantificadores "standard", que obtinha por um processo algorítmico resultados inteiramente condizentes com nossas intuições sobre seus usos mais conhecidos, o cálculo dos predicados pôde apresentar-se desde Tarski como uma linguagem rigorosamente composicional, tanto de um ponto de vista sintático como semântico, que estabelecia um padrão de simplicidade e explicitude a ser alcançado no estudo da lingua natural. 
É difícil superestimar esse resultado. Do ponto de vista teórico, ele pode ser comparado à proposta chomskiana de entender gramática como um conjunto finito de regras, capazes de definir uma linguagem infinita: em ambos os casos mostra-se um método matemático para dominar a infinitude da língua que corresponde à célebre intuição de Humboldt, segundo a qual a língua "faz um uso infinito de meios finitos". O fundamento dos dois processos é aliás o mesmo: a recursão, a característica já citada das línguas naturais, pela qual as operações (sintáticas ou semânticas) que foram aplicadas para obter determinados construtos se aplicam por sua vez sobre esses mesmos construtos, sendo exemplos óbvios o encaixamento de sentenças em sentenças e a possibilidade de negar uma negação.

O cálculo de predicados foi freqüentemente utilizado como o núcleo de linguagens através das quais se procurava explicitar a forma lógica das sentenças das línguas naturais: é o que acontece por exemplo nas teorias com que Davidson procura explicitar a forma lógica das sentenças de ação e das sentenças dependentes de verba dicendi (DAVIDSON, 1967, 1969), em várias teorias do tempo e do aspecto (por exemplo, DOWTY, 1979) e em muitas teorias que procuraram explicar a semântica da sentença a partir do significado das palavras componentes, desde WEINREICH (1963) e BIERWISCH (1969), e em muitos outros estudos. ${ }^{7}$ Esses estudos são habitualmente reunidos sob o nome genérico de "semântica formal", um termo que faz justiça ao caráter explícito das explicações que busca, mas que, em compensação, tende a esconder a profunda diferença de orientações que abriga.

Para que essa diferença de orientações fique pelo menos apontada, dedico os próximos parágrafos a caracterizar aquela que me parece ser a principal linha divisória no interior da semântica formal: a escolha entre uma orientação tipicamente extensionalista (representada por Davidson) e uma orientação intensionalista (representada por Montague). Desde já, esclareço que, ao opor essas duas orientações no interior da semântica formal, meu único interesse é desfazer a crença, injustificada mas corrente entre nossos 
lingüistas, de que todas as semânticas formais são uma única e mesma coisa. Não pretendo, aqui, defender a superioridade desta ou daquela linha da semântica formal, mas tão-somente mostrar que a despeito de sua diversidade, elas exibem algumas características comuns particularmente salientes. Essas características comuns serão resumidas no final desta secção; meu propósito é definir a partir delas um certo "fazer semântico" ao qual pretendo opor um "fazer pragmático" de que tratará a segunda parte deste escrito.

Uma das mais importantes versões da semântica formal, representada por Donald Davidson (que a mantém coerentemente a partir de DAVIDSON, 1967), não só incorpora a proposta de Tarski, mas defende a tese bem mais radical, de que uma semântica adequada para as línguas naturais nada mais é que uma teoria da verdade à maneira de Tarski.

Essa posição é marcadamente extensionalista, já que opta por reconstruir em termos de verdade - ou seja extensionalmente ${ }^{8}-\mathrm{a}$ noção intensional do sentido, a que recorrem mais habitualmente as teorias semânticas da sentença. O extensionalismo de Davidson parece ter origem nas idéias de Quine, para quem as intensões são entidades suspeitas, pois não dispomos de critérios claros que nos permitam decidir quando estamos diante de uma mesma intensão.? Endossando as idéias de Quine, Davidson coloca sob suspeita o operador

“... significa que..."

e propõe que ele seja substituído pelo operador do esquema T de Tarski,

“... é verdadeira se e somente se ...”.

Essa "manobra" de Davidson é radical se a referirmos à maneira como se configurou historicamente o estudo da significação e aos objetos a que se dedicou tradicionalmente esse estudo; de fato, a maioria das teorias semânticas, de procedência lógica ou lingüística, deram prioridade não às extensões (objetos. conjuntos de objetos 
e valores de verdade), mas às intensões (idéias, sentidos, propriedades...); referida à atividade lingüística dos falantes, a manobra de Davidson encontra contudo uma justificação na constatação de que, com base no conhecimento do sentido de um enunciado, qualquer locutor é capaz de decidir em que situações (reais ou possíveis) esse enunciado é verdadeiro: dizer o sentido de um enunciado, então, nada mais seria que explicitar suas condições de verdade. ${ }^{10} \mathrm{~A}$ manobra de Davidson não está totalmente isenta de dificuldades, quando se trata de caracterizar a significação das sentenças; para validá-la, exige-se na realidade que ela seja avaliada à luz de um contexto teórico e filosófico bem mais complexo do que seria exigido para decidir da adequação descritiva da maioria das análises lingüísticas. Não há dúvida porém de que é possível dar conta de muitos fenômenos lingüísticos numa perspectiva rigorosamente extensional, como a que Davidson preconizou.

Na outra grande versão da semântica formal, a "Gramática de Montague", assume-se a intensionalidade como uma característica geral da linguagem natural, que o cálculo semântico precisa reproduzir formalmente. Para tanto, a Gramática de Montague traduz as frases da linguagem corrente em fórmulas de uma linguagem capaz de representar e de calcular intensões. Essa capacidade da linguagem em questão, IL, é alcançada pelo uso de meios (meta-) matemáticos relativamente complexos, aliados ao uso de uma arquitetura teórica bem mais complexa. Mas o programa geral da teoria semântica continua sendo o de explicitar condições de verdade, um programa que de resto Montague procura realizar mediante procedimentos estritamente composicionais e "disquotational”.

Em suma, o exemplo de seus representantes mais influentes mostra que a "semântica formal", a despeito da variedade dos programas de pesquisa em que consiste, trata basicamente de condições de verdade de sentenças e procura estabelecê-las segundo um método em que são relevantes as seguintes características: 
- atribui-se um papel semântico às unidades sintáticas elementares e aos processos sintáticos de construção;

- $\quad$ concebem-se a sintaxe e a semântica da língua como disciplinas paralelas, entendendo que a cada regra de construção sintática corresponde um certo processo de composição semântica;

- respeita-se o princípio de funcionalidade (ou "composicionalidade") pelo qual as propriedades semânticas das expressões complexas são função das propriedades semânticas de seus constituintes;

- $\quad$ adota-se o procedimento "disquotational" como recurso para obter a representação semântica de qualquer expressão por meio de um conjunto infinito de passos.

Fica claro que, por esses métodos, a Semântica se vê comprometida a catalogar expressões e a formular "regras semânticas" para todas as unidades lexicais e todas as regras gramaticais, uma tarefa que se poderia assimilar por certos aspectos à de um "manual de instruções", e que, por procurar sistematicamente as correspondências entre as unidades da língua objeto e sua "tradução" na metalinguagem, pode ser assimilada à de um "manual de tradução".

A metáfora do manual de tradução e as restrições que, razoavelmente, se podem fazer a um manual de tradução, ajudam a compreender o salto qualitativo que ocorre quando se passa da semântica para a pragmática.

\section{O PROGRAMA DA PRAGMÁTICA NAS PROPOSTAS DA BIBLIOGRAFIA}

Seria temerário esperar de uma teoria semântica que adote o programa descrito nas páginas que precedem, que ela dê conta de todos os aspectos efetivamente envolvidos na interpretação de uma sentença. De fato, o que chamei de "manual de tradução" não serve nem mesmo para tratar desse aspecto extremamente limitado (embora essencial) da interpretação a que se tem chamado tradicionalmente "o sentido literal". ${ }^{11}$ Os primeiros a saber disso são os próprios representantes da "semântica formal", sendo exemplar o tratamento que Davidson dá à metáfora em outro artigo célebre. ${ }^{12}$ 
Entretanto, as acusações de reducionismo têm sido constantes em nosso meio lingüístico, e têm adotado geralmente uma estratégia em dois momentos: no primeiro momento, aponta-se para fenômenos lingüísticos que evocam a idéia morrisiana de envolvimento dos interlocutores; no segundo momento, procura-se mostrar que é impossível teorizar sobre eles no quadro de uma "semântica formal", e exigem-se complicações da teoria lingüística que constituiriam o cerne de uma teoria pragmática a ser desenvolvida. Para situar a concepção de pragmática que defendo para meu uso, vale a pena recordar algumas dessas críticas.

\subsection{Os dêiticos}

Um dos primeiros fenômenos a ser apontado como irredutível a um tratamento semântico foi a dêixis. Sabidamente, dêiticos típicos como eu, aqui, agora retiram sua referência de componentes do contexto extralingüístico em que são pronunciados; e o emprego correto de outros dêiticos menos lembrados depende de certas condições contextuais fortes. Por exemplo, o uso dos verbos ire vir, em

(18) a. Você vai para a festa amanhã à noite?

b. Você vem para a festa amanhã à noite?

subentende (ou pressupõe?) que a pessoa que os pronuncia esteja respectivamente afastada do local da festa ou situada nele (eventualmente, essa "situação" será psicológica: alguém muito envolvido com os preparativos da festa poderá pronunciar b. mesmo que, em termos estritamente físicos, fale de outro local); num sentido análogo, LEMOS (1985) mostra que numa ocorrência de

(19) A orla marítima está a cerca de três quilômetros

a escolha de estarao invés de outros possíveis verbos de localização (como ser e ficar) pode indicar que o locutor está em movimento, por exemplo porque está-se deslocando de carro numa rodovia que corre paralela à costa. ${ }^{13}$ Em resumo, a regra básica de interpretação 
das expressões dêiticas consiste em procurar sua referência no contexto em que são produzidos os enunciados lingüísticos que as contêm, e a semântica, concebida como uma análise do sentido inerente às expressões (em oposição às suas ocorrências), ficaria impossibilitada de explicar esse procedimento interpretativo.

Num texto que chegou a ser visto como o programa de uma pragmática independente, STALNAKER (1972) reflete sobre as complicações que os dêiticos trazem para uma semântica das condições de verdade. Essencialmente, Stalnaker constata que devido à existência de dêiticos, o estudo das condições de verdade não pode ser feito para sentenças, mas deve ao contrário aplicar-se às significações que as sentenças assumem em suas várias enunciações.

Considerem-se, a título de aplicação e exemplo, estas passagens transcritas da Folha de S.Paulo de 23/7/91, (Revista D, Secção "Retrato Falado"):

(20) "Ele é um amante adorável"

(21) "Ele é um amante adorável, eu rodaria mil vezes aquelas cenas"

(22) "Ele tem um sorriso de serpente"

As frases entre aspas eram a respeito do ator Jack Nicholson, assunto do Retrato Falado daquele dia; com o objetivo de facilitar sua análise, a sentença (20) foi recortada da passagem (21), que é por sua vez um comentário da atriz Jessica Lange sobre o filme $O$ destino bate à porta, rodado em 1981, e famoso por algumas cenas "quentes".

Para dar conta do fato de que as condições de verdade de (20), (21) e (22) dependem do contexto em que foram pronunciadas, Stalnaker lança mão do conceito de proposição, redefinido como "o conjunto das condições de verdade que uma sentença assume numa enunciação particular”. Graças a essa definição, ele pode distinguir claramente entre as sentenças - unidades sintáticas de uma dada língua e as proposições - unidades semânticas que em princípio independem de sua expressão numa língua natural específica. Aplicada ao texto sobre Jack Nicholson, essa distinção resulta em 
reconhecer que Jessica Lange não usou de fato a sentença (21) (porque não fala português), mas afirmou (em inglês) a mesma proposição que vem expressa em (20).

Com essa definição de proposição torna-se possível - segundo Stalnaker - delimitar de maneira precisa a sintaxe, a semântica e a pragmática de uma língua natural, como disciplinas que tratam, respectivamente, de três objetos teóricos bem distintos - respectivamente as sentenças, as proposições e os atos e contextos de fala. A divisão de trabalho assim esboçada é clara:

- $\quad$ reconhecendo nas sentenças e suas descrições sintáticas um papel sobretudo evidencial (no sentido de que levantam pistas sobre diferenças nas condições de verdade), o semanticista assume a tarefa de formular as proposições que lhes correspondem. Ele opta por desconsiderar quaisquer outros aspectos da sentença que não as proposições que ela expressa; e formaliza a intuição de que um enunciado é verdadeiro ou falso dependendo do que significa e de como é o mundo, entendendo a proposição como uma função que vai de mundos a valores de verdade. Num contexto de fala como o do artigo da Folha, em que o assunto é Jack Nicholson, a sentença (22) exprimirá a proposição "Jack Nicholson tem um sorriso de serpente", que, aplicada ao mundo real, resulta numa afirmação verdadeira.

- O pragmaticista volta-se ao contrário para o estudo dos "atos e produtos de fala". Diante de um texto como o da Folha, cabe a ele reconhecer que a sentença (20) foi pronunciada como parte de um ato de fala assertivo, e que (21) vale por uma espécie de promessa, aliás carregada de subentendidos a esclarecer. Deve também esclarecer que (20) corresponde a proposições diferentes conforme os contextos em que é usada, pois as condições de verdade de (20) se alterariam com certeza se o Retrato Falado em questão fosse dedicado a Charles Chaplin, Zé do Caixão ou Mazzaropi.

A indiscutível clareza da distinção entre contextos e mundos levou Stalnaker a polemizar com as orientações da semântica formal que atribuem a esses dois elementos um papel análogo, reunindoos. ${ }^{14}$ Assumindo essa posição, Stalnaker descarta (23), que seria insuficiente precisamente por reunir num mesmo componente os contextos e os "atos e produtos de fala", 


$$
\begin{aligned}
& \left\{<\mathrm{MP}_{1}, \mathrm{C}_{1}>, \quad<\mathrm{P}_{1}, \mathrm{C}_{2}>, \quad<\ldots . .>,\right. \\
& \left.<\mathrm{MP}_{\mathrm{n}}, \mathrm{C}_{\mathrm{m}}>\right\}
\end{aligned}
$$

os parênteses angulares identificam um índice cujas coordenadas são um mundo possível e um contexto

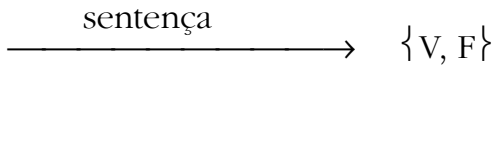

a seta indica mapeamento dos índices em valores de verdade

\section{e adota um modelo de teoria linguística como o expresso em (24):}

$$
\begin{aligned}
& \text { Sentença ou } \\
& \text { frase interpretada } \\
& \left\{\mathrm{MP}_{1}, \mathrm{MP}_{2}, \ldots, \mathrm{Mp}_{\mathrm{n}},\right\} \\
& \text { proposição } \\
& \text { mundos possíveis } \\
& \text { (mapeamento em) } \\
& \text { valores de verdade }
\end{aligned}
$$

\section{Essa decisão leva Stalnaker a analisar (21) não como (25),}

$<$ no mundo real e no contexto de fala sobre Jack Nicholson >

a sentença "ele é um amante adorável"

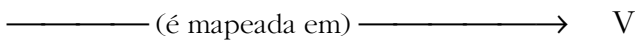

mas como (26):

(26) No contexto de fala sobre Jack Nicholson

A sentença "ele é um amante adorável" é mapeada numa 
Para defender (26), Stalnaker empenha-se didaticamente em provar que (25) é um esquema inadequado, embora à primeira vista mais atraente por ser mais simples. Todos os seus argumentos apelam para o fato de que, nas representações baseadas em (25), a proposição, tal como ele a definiu, não aparece como uma unidade à parte; com isso, perder-se-ia a possibilidade de dar conta de certas capacidades que atribuímos intuitivamente aos falantes. Eis algumas dessas capacidades, envolvendo, precisamente, o tratamento da dêixis:

- distinguir possíveis motivos de discordância quanto à verdade ou falsidade de uma afirmação - assim, duas atrizes diferentes poderiam discordar quanto à veracidade de (21), quer porque não estão falando da mesma pessoa (isto é, porque estão falando de um "ele" diferente), quer porque a primeira é menos exigente que a segunda em matéria de parceiros sexuais. No esquema mais complexo, (26), a primeira dúvida diz respeito à flecha vertical, a segunda à flecha horizontal).

- reconhecer o contéudo comum de uma pergunta e de sua resposta "natural". Por exemplo,

(27) Sim, (20)

é a resposta natural de

(28) É verdade que Jack Nicholson é um grande amante? Para definir resposta natural é necessário apelar para a noção de proposição (uma pergunta polar e sua resposta natural têm em comum a mesma proposição), e isso é algo impossível de ser mostrado em (25).

- Distinguir maneiras alternativas de interpretar sentenças em que intervêm simultaneamente expressões dêiticas e operadores modais. Assim, esta sentença, escrita num muro qualquer:

(29) Isto não devia estar escrito aqui

é falsa, segundo Stalnaker, qualquer que seja o lugar e o momento em que deparamos com ela (pois toda frase escrita está sempre e necessariamente escrita no lugar em que está escrita e o verbo dever traduz essa idéia de necessidade); mas por outro lado é perfeitamente possível imaginar um mundo em que (29) teria sido rabiscada 
num outro muro. Num primeiro caso, interpreta-se a sentença como remetendo a contextos possíveis; no segundo, como remetendo a mundos possíveis.

Stalnaker defende, em suma, a necessidade de um estudo especificamente voltado para os elementos da interpretação que se originam no contexto: é a esse estudo que ele chama de pragmática, em oposição à investigação das condições de verdade de uma sentença. Nessa definição de pragmática, os fatores contextuais e mais particularmente a dêixis têm um papel preponderante, como procurei deixar claro. ${ }^{15}$ Ainda assim, minha avaliação desse programa é que, embora a distinção de duas ordens de fatores esclareça a origem de algumas ambigüidades intuitivamente percebidas, não é um argumento decisivo para fundar uma pragmática, por uma razão fundamental: o tratamento proposto tanto para os mundos quanto para os contextos baseia-se no único recurso (aliás matematicamente neutro) da função, o que está a indicar que, embora estejamos diante de repertórios distintos de escolhas, o procedimento pelo qual se representa teoricamente a contribuição dos fatores semânticos e pragmáticos é, metodologicamente falando, o mesmo.

Como eu já disse, acredito que se deve falar em pragmática para um tipo de interpretação mais complexa do que as interpretaçôes semânticas correntes; como se verá, num tratamento pragmático, é a própria noção de função que tem sua aplicação prejudicada: imaginar que existam funções especificadas é estabelecer para os fenômenos pragmáticos uma possibilidade de cálculo que se realiza de maneira por assim dizer mecânica, dedutiva, e isto é o oposto do que eu entendo por pragmática.

\subsection{A pressuposição}

Outro fenômeno lingüístico que pareceu apontar para a necessidade de estudar a significação por um enfoque incompatível com o que vinha sendo adotado pela semântica, e nesse sentido contribuiu para o desenvolvimento de pesquisas que foram 
reconhecidas como autenticamente pragmáticas, foi a pressuposição, cuja identificação como um fato digno de atenção específica costuma ser localizada no celebre texto de Frege Über Sinn und Bedeutung (FREGE, 1892), ainda que o fenômeno já tivesse sido reconhecido e descrito bem antes. ${ }^{16}$ Como se sabe, Frege recorreu à noção de pressuposição, naquele texto, ao tratar dos exemplos (30) e (31), no contexto de uma reflexão em que visava a determinar o papel desempenhado pelas orações subordinadas na construção do sentido, e sobretudo da referência, do período gramatical: ${ }^{17}$

(30) Quem descobriu a forma elíptica da órbita dos planetas morreu na miséria

(31) Depois que o Schleswig-Holstein se separou da Dinamarca, a Áustria e a Prússia se desentenderam.

Ao analisar o primeiro exemplo, Frege mostrou que a negação não afetava a informação de que "existiu alguém que descobriu a forma elíptica das órbitas dos planetas": tomando a insensibilidade à negação como critério, concluiu que essa informação não fazia parte dos conteúdos assertados pela sentença (30), e usou o termo pressuposição para distingui-la. A análise que Frege fez do exemplo (30) no artigo de 1892 lançou, simultaneamente, dois grandes temas: o da existência de conteúdos implicitamente presentes na oração, cuja natureza seria preciso compreender; e o da possibilidade de aplicar aos conteúdos de uma sentença testes que poderiam apontar para diferentes níveis de processamento semântico.

A propósito de exemplos como (30), Frege formulou ainda um problema que, pelo século XX afora, seria objeto de um debate muito importante para a história da pragmática. Sentenças como (30) - e de resto todas as sentenças cujo sujeito gramatical é representado por uma descrição definida - pressupõem que existiu alguém com as características expressas pela descrição. O que fazer quando essa pressuposição é contrária aos fatos - quando, por exemplo, alguém afirma (32) nas condições atuais (maio de 2000)?

(32) O rei da França é um demagogo de direita 
As duas soluções clássicas para esse problema são antecipadas por Frege e são representadas, como se sabe, por Russell (1905) e Strawson (1956).

Russell desenvolveu sua célebre "Teoria das Descrições" que, definindo "contextualmente" o rei da França, reduz a asserções todas as informações da sentença problemática. Por essa teoria, (32) é parafraseada como

(33) (Existe no máximo um indivíduo x que é rei da França) \& (Existe no mínimo um indivíduo x que é o rei da França) \& (x é demagogo de direita).

Por essa paráfrase, (33) era falsa na época em que foi escrito este trabalho, pois, sendo a França uma república, e sendo Jacques Chirac seu presidente e não seu rei, a segunda sentença da fórmula (33) é falsa.

A análise de Strawson também foi antecipada por Frege. Ela se opõe explicitamente à proposta de Russell, e foi compreensivelmente saudada como uma proposta de análise pragmática das pressuposições: de fato Strawson defende que há três níveis em que uma sentença pode ser analisada: como tipo, como ocorrência e como uso. Para Strawson, falar da verdade de sentenças como (32) só se justifica se elas forem consideradas enquanto ocorrências ou usos, não enquanto tipos; um dos possíveis usos de (32) e congêneres é quando as pressuposições correspondentes à descrição definida não se realizam: nesse uso, a sentença não será nem verdadeira nem falsa, mas simplesmente descabida. A análise de Strawson caracterizava as pressuposições como uma forte condição contextual para que um valor de verdade pudesse ser atribuído às sentenças, e isso levou naturalmente a encarar esse fenômeno como um argumento a favor de uma pragmática autônoma.

À mesma conclusão - de que o estudo das pressuposições exige um enfoque pragmático sobre a linguagem - chega-se igualmente quando a pressuposição é interpretada não como uma informação veiculada pelas sentenças, mas como um ato de fala. Ducrot adotou essa via já em Dire et ne pas Dire (DUCROT, 1972), caracterizando a pressuposição como um ato de fala por meio do 
qual o locutor estabelece condições para o debate lingüístico, impondo "verdades" que seu interlocutor não poderá recusar sob pena de transformar o diálogo em polêmica. Seus principais continuadores brasileiros (sobretudo VOGT, 1976 e GERALDI, 1978), ao tratarem de pressuposição e de vários outros tipos de implícitos, foram ainda mais diretos em adotar como pano de fundo para seus próprios estudos uma concepção das funções da linguagem que desqualifi-cava os aspectos representacionais e valorizava como paradigmá-ticos os usos voltados para o envolvimento, a negociação e a interação.

Sem negar que o uso adequado de sentenças que veiculam pressuposições remete a condições contextuais, não me parece sempre necessário invocar o contexto para explicar as pressuposições de um enunciado. Em muitos casos, seu papel se deixa captar satisfatoriamente por uma lógica trivalente que, ao lado do verdadeiro e do falso, reconheceria um terceiro valor "indeterminado".

Embora reconhecendo que a Semântica Argumentativa tornou visível uma série de recursos de que a linguagem lança mão para fins de argumentação ou de orientação do interlocutor, tenho certeza de que a análise das pressuposições não exige um enfoque pragmático no sentido que eu gostaria de dar a esse termo. Estou procurando reservar à pragmática o estudo das interpretações que são intuitivamente válidas, mas não são convencionais nem passíveis de ser calculadas. Ora, uma autêntica pressuposição é sempre previsível e convencional. Ela é sempre disparada pela presença na sentença de uma ou outra construção gramatical ou palavra e prende-se sistematicamente ao sentido dessas unidades. ${ }^{18}$ Somente assim podese compreender que autores como Fillmore tenham descrito as pressuposições como um tipo de informação lexical (FILLMORE, 1969) e que, num confronto com as categorias da pragmática griceana, as pressuposições tenham sido geralmente equiparadas às implicaturas convencionais.

As pressuposições são tão evidentemente calculáveis, que foi possível formular para elas o chamado "problema de projeção", que 
consiste em estabelecer em que condições as pressuposições veiculadas por uma determinada oração se mantêm quando essa oração aparece encaixada em outra, como oração subordinada: há com efeito fortes diferenças quanto ao conjunto de pressuposições que se podem atribuir a sentenças como:

(34) José observou corretamente que Pedro está a par de que André parou de fumar.

(35) José comentou que Pedro disse que André parou de fumar.

Um artigo célebre de KARTTUNEN (1971) mostra que as pressuposições das sentenças encaixadas se preservam ou não no período complexo, conforme o verbo regente e o tipo de conectivos que as introduzem.

Todos esses aspectos dão às pressuposições um caráter altamente gramaticalizado e integrado.

\subsection{Os performativos}

Ao tratar de pressuposição nos parágrafos que precedem, lembrei que alguns autores deram a esse fenômeno um tratamento que o equipara a um verdadeiro ato de fala entre tantos outros possíveis. Numa mesma linha de análise que dá realce ao papel do locutor, todos os atos de fala que possamos distinguir, desde os que a língua associa à forma assertiva ou interrogativa do enunciado, até os que mais comumente se referem ao modo verbal (indicativo/ imperativo/subjuntivo, indicando asserção, ordem ou volição), poderiam em princípio ser invocados como argumentos para advogar um tratamento pragmático das línguas naturais.

A força desse argumento não é contudo maior que a do argumento baseado nos dêiticos ou nas pressuposições que, como procurei mostrar, se tornam passíveis de cálculo semântico desde que se façam neste último algumas modificações que vão no sentido da complicação técnica, mas não da alteração de seus princípios fundamentais. 
Minha afirmação poderia ser entendida como uma atitude de pouco-caso para com os ensinamentos que a teoria dos atos de fala acumulou a respeito das línguas naturais. Além disso, ela soa paradoxal quando se pensa que a maioria dos manuais de pragmática dedicam capítulos inteiros aos atos de fala, e que alguns pragmaticistas célebres (estou pensando em Jef Verschueren, por exemplo) dedicaram grande parte de sua atividade intelectual a teorizar sobre atos de fala.

Para desfazer essa sensação de paradoxo, nada melhor do que examinar expressões crucialmente envolvidas na realização de atos de fala específicos, perguntando se as explicações que nos dão conta de seu funcionamento são de ordem semântica ou pragmática, segundo a definição que estou tentando justificar. Para essa análise, recorro aqui ao caso dos verbos performativos, uma escolha que me parece óbvia por ter sido essa classe, historicamente, uma espécie de protótipo ou emblema dos demais atos de fala e uma espécie de bandeira na defesa de um tratamento diferenciado.

Lembro, por mera precaução didática, que a noção de performativo, enquanto aplicada a expressões lingüísticas, é bem menos abrangente que a de ato de fala, e é aliás extremamente específica: só se enquadram na classe dos performativos os verbos que, utilizados (em condições adequadas) na primeira pessoa do presente do indicativo resultam em realizar o ato de fala que as outras formas verbais apenas relatam. Por essa definição extremamente restritiva, penso que muitos lingüistas evitariam qualificar como performativos os termos assinalados nos diálogos a seguir, a despeito de serem eles que, no contexto, criam uma situação "jurídica" nova:

(36) A - Você quer ficar com meu cachorro, de presente?

B - Quero.

(37) A - Quer casar comigo?

B - Quero

(38) A - O senhor reconhece este elemento como o assaltante que lhe esfaqueou no dia $17 / 10$ ?

B - Reconheço. 
(39) A - O senhor já se decidiu por algum desses bonés?

B - Fico com este.

Embora eu não conheça nenhum estudo exaustivo feito a esse respeito para o português, isso me leva a crer que o número total de verbos performativos típicos é pequeno relativamente ao total de ações que se efetivam graças à intervenção da língua. Em compensação, o contraste do uso autenticamente performativo com os demais é fortemente marcado, e é perfeitamente compreensível que, de acordo com a lição de AUSTIN (1958, 1962), esse contraste tenha levado, por sua vez, a contrastar performativo e constativo não apenas como uma alternativa que biparte as formas da conjugação verbal, mas como uma alternativa que opõe duas maneiras de entender a função e a natureza da linguagem.

Quase todos os autores que, como Austin, contrastaram um enfoque constativo e um enfoque performativo acabaram por entender que a função constativa deveria ser subordinada à função performativa, ou seja, concluíram que informar é apenas uma entre várias ações que podemos realizar lingüisticamente. Esse deslocamento, que é de pouco posterior a outro deslocamento célebre, realizado por Wittgenstein desde uma teoria da linguagem como representação do mundo para uma teoria da linguagem como jogo, permitiu situar em chave mais correta uma quantidade de fenômenos lingüísticos que resultariam distorcidos numa descrição estritamente representacional, e foi nesse sentido extremamente positivo. No Brasil, onde nunca se chegara a fazer uma boa semântica de orientação constativa, ele permitiu, por uma espécie de reação a uma ortodoxia que ninguém havia jamais praticado, a criação do clima em que se desenvolveu a semântica argumentativa dos anos 70, cujo tema central foi por muito tempo a pressuposição.

De minha parte, reconheço que a adoção de um enfoque performativo abriu novas perspectivas para o estudo da língua natural, mas resisto a afirmar que isso tenha resultado, por si só, na constituição de uma pragmática. Algumas das inadequações que foram então imputadas às análises semânticas de tradição constativa 
são irreais, e uma delas é a que se formula precisamente a propósito dos verbos performativos, quando se diz que uma sentença como

(40) Eu vos declaro marido e mulher

por constituir uma ação e não um relato, não tem valor de verdade. A especificidade do verbo performativo não consiste nisso, mas, ao contrário, no fato de que ele confere à sentença de que faz parte a singular propriedade de tornar verdadeira uma certa proposição precisamente pelo fato de ser pronunciada.

Mas a razão de minha resistência a aceitar que a abertura para os performativos cria uma pragmática é outra, e tem um fundamento metodológico: a maior parte dos fenômenos e efeitos de significação que passaram a receber a atenção dos lingüistas eram, ainda, fenômenos calculáveis. Quero dizer com isso que uma frase como (46) pode ser objeto de uma análise do tipo (47):

(41) 'pij-te varda

(42) "pij-te varda" usa-se (em Piemontês) para desestimular um atrevimento do interlocutor.

É claro que (42) é mais complexo que as fórmulas baseadas na convenção T de Tarski, nas quais foi inspirado. Mas como na convenção T há uma tradução, e essa tradução parte das informações (de ordem gramatical e lexical) proporcionadas pelo enunciado da linguagem-objeto.

Como no caso das pressuposições, muitos elementos autenticamente pragmáticos vieram, sim, à tona, graças à atenção dada aos atos de fala: um deles é o constituído pelos atos de fala indiretos: na medida em que alguns deles não são convencionalizados, o tipo de ato (e às vezes também o conteúdo proposicional) precisam ser "adivinhados" ou recuperados a partir de pistas contextuais. No caso das pressuposições, seu estudo havia levado a distinguir pressupostos e implícitos, e o mecanismo pelo qual se engendram os conteúdos implícitos, bem mais aleatório que o das pressuposições, não obedece normalmente a um procedimento calculável. Nesses casos - mas só neles - faria talvez sentido falar em pragmática. 


\subsection{As implicaturas conversacionais}

O procedimento interpretativo que exemplifica da maneira mais completa as condições de uma interpretação autenticamente pragmática é a implicatura conversacional. Reportemo-nos ao exemplo clássico de Grice, para realçar essas condições:

"Suponha que A e B estejam conversando sobre um amigo comum $C$ que está, atualmente, trabalhando num banco. A pergunta a $B$ como C está se dando em seu emprego, e B retruca: Oh, muito bem, eu acho; ele gosta de seus colegas e ainda não foi preso. Neste ponto, $A$ deve procurar o que $B$ estava implicando, o que ele estava sugerindo ou até mesmo o que ele quis dizer ao dizer que $C$ ainda não tinha sido preso. A resposta poderia ser algo do tipo "C é do tipo de pessoa que tende a sucumbir às tentações provocadas por sua ocupação", ou "os colegas de C são, na verdade, pessoas muito desagradáveis e desleais" e assim por diante. Naturalmente, será desnecessário A fazer qualquer pergunta a $B$, pois a resposta, no contexto, é antecipadamente clara. Penso que é claro que tudo o que B implicou, sugeriu, significou, etc., neste exemplo é distinto do que $B$ disse, que foi simplesmente que C não tinha sido preso ainda..."19

Tendo em mente um público disposto a atribuir à linguagem um papel essencialmente informativo e a entender que quaisquer informações veiculadas por um enunciado podem ser deduzidas desse enunciado por um mecanismo de inferência ou implicação lógica, Grice sentiu antes de mais nada a necessidade de insistir que o mecanismo pelo qual (44) resulta de (43)

(43) Oh, muito bem, eu acho; ele gosta de seus colegas e ainda não foi preso

(44) "Cé do tipo de pessoa que tende a sucumbir às tentações provocadas por sua ocupação", ou "os colegas de C são, na verdade, pessoas muito desagradáveis e desleais" e assim por diante

não é a implicação ou acarretamento logico (pois as informações de (44) não estão nem ditas nem implicitamente contidas em (43)), mas um procedimento conversacional a ser melhor compreendido, para o qual Grice cunhou o termo especial de implicatura. 
A teoria da relevância conversacional estabelece as condições mais gerais em que um enunciado, ao invés de ser interpretado em seu sentido primeiro, funciona, conversacionalmente, como um desencadeador de implicaturas. Como se sabe, essa teoria compreende 4 máximas que dispõem sobre a informação a ser veiculada pelos enunciados (qualidade, quantidade, relação e modo), além de um princípio geral - o de cooperação - que dispõe sobre os propósitos mais gerais de toda interação comunicativa. A relação entre as máximas e o princípio de cooperação é tal que a transgressão de uma máxima é normalmente interpretada como uma tentativa de garantir que o princípio de cooperação seja preservado. Assim, uma resposta como (43) seria normalmente encarada como irrelevante para a pergunta feita (transgressão da máxima do modo), mas essa irrelevância, ao invés de ser entendida como uma transgressão gratuita, pode ser justificada pela preocupação de informar apesar de tudo: o locutor poderia ter usado (44) ao invés de (43), por exemplo, porque não dispõe de provas seguras da desonestidade de $\mathrm{C}$ ou da deslealdade de seus colegas bancários, e assim por diante.

O raciocínio que gera implicaturas produz sentido inserindo num todo coerente um enunciado que, à primeira vista, constituía um problema precisamente por seu sentido. Não visa a recuperar informações que decorrem regularmente do enunciado, mas a criar um novo tipo de organização da interação verbal, no qual fazem sentido as informações que ele permite descobrir. Uma implicatura autenticamente conversacional é por definição altamente imprevisível, obedecendo, como único princípio geral, à condição de que os interlocutores agem como parte de uma única "atividade de coordenação" em que todas as pistas são em princípio válidas. A pergunta a que se responde para alcançar a implicatura é, aliás, a mesma que fundamenta todas as atividades de coordenação marcando-as como manipulações de imagens recíprocas: "o que pode ele querer, para me dizer isso?". ${ }^{20}$ 


\section{A PRAGMÁTICA COMO O AVESSO DA INTERPRETAÇÃO CALCULÁVEL}

Admitindo que os dêiticos, as pressuposições e os valores ilocucionários são aspectos sistemáticos e previsíveis da interpretação do léxico e das construções gramaticais, reivindicarei que sejam encarados como objetos de estudo da semântica, possivelmente de uma semântica formal. Reconheci, em oposição a eles, um grande exemplo privilegiado de fenômeno pragmático: as implicaturas. Deixei clara também a razão por que, em minha opinião, as implicaturas merecem esse destaque, a saber, o fato de que, enquanto mecanismo interpretativo, mobilizam um tipo de competência que se distingue da aplicação correta de um algoritmo. Essa escolha das implicaturas como protótipo dos fenômenos pragmáticos permite ilustrar o conceito de pragmática que está sendo defendido aqui, que é o de pragmática como o domínio das interpretações não-calculáveis. ${ }^{21}$

A idéia de que as interpretações dos enunciados lingüísticos podem ou não receber uma interpretação algorítmica é antiga. Provavelmente, essa dupla possibilidade foi atentamente considerada pelos lógicos de Port Royal, quando decidiram chamar de "Arte" e não "Ciência do pensar" seu compêndio da lógica aristotélica: com efeito, eles tinham clareza de que suas regras lógicas não permitiam dar conta formalmente de algumas inferências que eram, entretanto, intuitivamente válidas, ${ }^{22}$ e isso recomendava caracterizar o trabalho do lógico como uma "Arte" e não como uma "Ciência". Se essa oposição esteve realmente presente no pensamento dos educadores de Port-Royal, eles aplicaram no domínio da interpretação dos enunciados uma distinção entre duas formas de auto-disciplina que começou a ser assinalada na Renascença por meio de fórmulas como "engenho e arte" ou "invenção e harmonia", que são essencialmente as mesmas formas de auto-disciplina, que Pascal denomina em seus Pensamentos "esprit de géométrie" e "esprit de finesse", cujo contraste dominou todo o seu século. Elas determinam duas atitudes intelectuais e sociais distintas, que podem ser vistas como complementares, mas que também podem resultar em programas de 
investigação específicos. No breve histórico da estética que faz em Aesthetica in nuce, CROCE (1913) lembra que, entre os séculos XVII e XVIII, os estudiosos da arte italianos criaram a expressão "nescio quid" para denominar uma faculdade judicativa diferente do juízo lógico, que ganharia um papel central na ciência poética de Vico, e que, sempre segundo Croce, teria influído na criação da Estética como disciplina autônoma por Baumgarten; essa faculdade judicativa reconhecia uma "verdade poética" que teria que ser julgada a partir do envolvimento do autor, segundo a definição de verdade dada por Vico, "verum ipsum factum". No outro sentido, propostas como o "calculus ratiocinator" de Leibniz e as várias tentativas feitas para dominar as noções matemáticas de função e de variável antecipam as tentativas de formalizar a significação dos enunciados, que começam a dar resultados nos séculos XIX e XX.

Seria temerária de minha parte qualquer tentativa de historiar o contraste entre um tratamento formal e um tratamento intuitivo da significação. É óbvio por outro lado que a distinção de dois processos continua válida como parâmetro que tem aplicação na interpretação dos enunciados lingüísticos e na maioria das atividades interpretativas que a mente humana realiza. Graças a essa circunstância, podemse encontrar em outras áreas de conhecimento reflexões altamente relevantes para a definição de pragmática, e uma dessas reflexões, particularmente aguda, é a que Rudolf Arnheim faz em seu livro Visual thinking (ARNHEIM, 1969) ao distinguir o modo como um computador e um cérebro humano identificam figuras.

O tema de Arnheim é a percepção, particularmente a percepção visual, encarada como ingrediente necessário a qualquer apreciação e educação artística nas chamadas artes visuais: não admira assim que a palavra pragmática nem sequer apareça em seu texto. Sua tese fundamental é que a percepção visual, longe de ser uma captação passiva de traços da realidade, envolve um trabalho inteligente e complexamente estruturado de organização. Ao expô-la, ele elabora um contraste entre a percepção humana e a maneira como ela é simulada pelo computador que, se não leva em conta os últimos 
avanços da inteligência artificial, tem certamente o mérito de ser altamente didática enquanto distinção de dois modos de atuar.

Essencialmente, a percepção visual aplica-se à realidade observando-a "from above": pode assim descobrir nela, de maneira imediata e sem a necessidade de cálculos, os esquemas topológicos que a organizam. Em contraste com a percepção visual humana, o computador realizaria suas tarefas de conhecimento visual "from below", mediante uma operação de scanning que converte a realidade percebida em um reticulado de pontos, mas que, a menos de estar programada para tanto, não tem como selecionar, entre as infinitas relações que poderiam ser estabelecidas sobre aquele reticulado, aquelas que efetivamente são capazes de organizar o real, e são portanto relevantes. Veja-se, em resumo, o que diz Arnheim da maneira como o cérebro humano e o computador reagiriam diante desta figura (figura 11, p. 75 do livro citado):

a

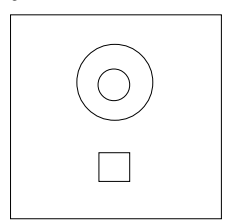

a

b
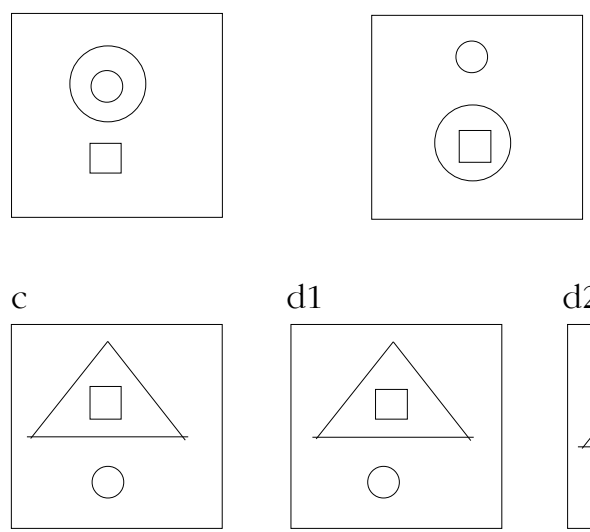

d1

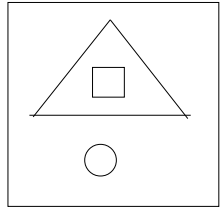

d2

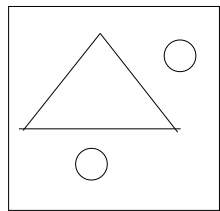

d3

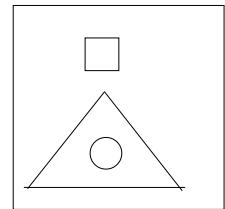


Quando os observadores humanos são confrontados com a figura a, tendem a notar algumas características de localização, tamanho relativo e forma; em particular, reconhecem um arranjo vertical formado por duas figuras, sendo que a de cima é maior e mais complexa que a de baixo. Os observadores humanos dão pouca importância aos valores absolutos das medidas dos lados e ângulos, que são ao contrário os elementos a partir dos quais o computador começa o seu trabalho de construção. Ao comparar a e b, os observadores humanos começam mais provavelmente por perceber uma semelhança apenas parcial, pouco convincente, entre as duas figuras; a igualdade ou simetria que poderia haver entre elas sofre a interferência de uma relação "diagonal", de modo que as duas figuras não se compõem num todo unificado, estável e compreensível. Subitamente, porém, os observadores humanos podem perceber que as figuras menores são estáveis, e apenas o círculo maior se desloca. Podem assim interpretar as duas figuras associando-as a um mesmo esquema básico, que se compõe de uma parte fixa, além de um ingrediente secundário, o círculo maior, que se desloca. Finalmente, os observadores humanos percebem com relativa facilidade uma proporção $\mathrm{a}: \mathrm{b}=\mathrm{c}: \mathrm{d} 3$. Plenamente acessíveis para qualquer criança, essas observações só são possíveis para um computador mediante um programação extremamente complexa, que desenvolve observações de caráter topológico a partir de observações de caráter quantitativo. Na realidade, é o programador que supre essas informações topológicas, o que significa que o o computador não participa da principal operação intelectual realizada - decidir quais são as relações relevantes para organizar o campo perceptual.

Ao recapitular as reações por que passam tipicamente os observadores humanos diante da Figura 1, Arnheim salienta ainda:

"This episode of perceptual problem solving has all the aspects of genuine thinking: the challenge, the productive confusion, the promising leads, the partial solutions, the disturbing contradictions, the flash appearance of a stable solution whose adequacy is selfevident, the structural changes brought about by the pressure of 
changing total situations, the resemblance discovered among different patterns. It is, in a small way, an exhilarating experience worthy of a creature endowed with reason; and when the solution has been found there is a sense of distension, of pleasure, of rest"(p.76-77).

Proponho reconhecer nessa descrição do problem solving perceptual os principais traços que eu havia apontado como peculiares no processo interpretativo que aplicamos às implicaturas, e que caracterizei como pragmático por excelência; saliento que tanto nas implicaturas como no problem solving perceptual, há necessidade de reduzir à ordem uma série de observações que parecem à primeira vista caóticas e portanto problemáticas. Essa ordem não é alcançada pela acumulação de detalhes ou por qualquer outro tipo de análise; exige ao contrário uma apreensão de conjunto dos dados disponíveis em que os elementos destoantes sejam situados e assimilados.

Seria uma injustiça para com Arnheim sugerir que, no problem solving perceptual, o observador impõe uma organização arbitrária aos dados que lhe são supridos pela observação, assim como seria uma injustiça supor que o observador seja, no momento da percepção, um mero registrador passivo. Mas o mesmo vale para os enunciados que interpretamos por implicatura: eles não são literais em sua significação, mas tampouco são arbitrários: propõem um problema específico, que o intérprete resolverá (ou não) aplicando aos dados disponíveis uma nova coerência em que o elemento problemático é absorvido e assimilado. Essa coerência buscada concerne aos dados, mas não resulta "automaticamente" deles, pois não é igual à sua soma.

O argumento a favor de uma pragmática autônoma baseado nas implicaturas é qualitativamente diferente dos demais, porque mostra o aparecimento de uma interpretação que, embora desencadeada a partir do sentido literal, não pode ser derivada dele por nenhum desenvolvimento calculável.

O processo pelo qual se reconhece e interpreta uma implicatura é expressamente caracterizado por Grice como um processo informal 
de "working out". Não tendo medida comum nem com a dedução (que intervém o cálculo das implicações), nem com a indução (que eventualmente confirma a interpretação de uma expressão ambígua, no interior de um mesmo texto, ou do idioleto pessoal de um autor, ou numa série de situações de fala análogas), esse processo tem sido freqüentemente explicado pelo mecanismo cognitivo da abdução palavra que remete imediatamente à epistemologia de Charles Sanders Peirce.

Peirce reconheceu a importância desses três mecanismos para o progresso do conhecimento, e refletiu em profundidade sobre o modo de operar e o interesse epistemológico de cada um. No fragmento 5.189, significativamente intitulado Pragmatics and Abduction, ele organizou didaticamente suas semelhanças e diferenças a partir do célebre exemplo dos feijões, que é assim retomado na Estética da Comunicação, de Herman Parret:

"In a syllogism, one reasons with the help of the following three categories: the rule, the case and the result. Abduction is the inference of a case. To take Peirce's own example, imagine a table with a can of beans on it, and lying beside it, a handful of loose beans. Deduction is presented in the following manner: RULE: All the beans from the can are white; CASE: the beans lying loose come form the can; I have the right to infer (without having to look, i.e., deductively) the RESULT: the loose beans are also white. Now for the inductive inference: observe that: CASE: the beans which are on the table came from the can; I observe that: RESULT: the beans are all white; I infer, whith a certain degree of probability and through induction, the RULE: all of the beans from the can are white. Abductive inference works like this: I know that: RULE: all the beans which are in the can are white; and in addition I see that: RESULT: the beans which are on the table are white; at that moment I infer abductively: CASE: the beans which are on the table originate from the can. This type of inference is a sophism if it is affirmed apodictically, but it is valid when it is presented as a hypothesis to be verified (inductively). Peirce describes the form of abductive inference in the following manner: "The surprising fact $C$ is observed; but if $A$ were true, $C$ would be a matter of course. Hence, there is reason to suspect that A is true'." (PARRETT, 1993, p.71) ${ }^{23}$ 
Nesse "experimento mental" de Peirce aparecem, por contraste com os processos indutivo e dedutivo as principais características da abdução:

- Ela comporta, antes de mais nada, a referência a um fato que surpreende e intriga - surpresa essa que dá a todo raciocínio abdutivo um caráter "problematológico";

- Basta imaginar que o raciocínio abdutivo leva a transitar entre diferentes estados de coisas, que ele tende a inscrever a observação problemática num curso de acontecimentos diferente daquele que foi inicialmente considerado, para reconhecer-lhe também um caráter potencialmente "narratológico", pois é sabido que a maioria das histórias se constroem como superação de um conflito inicial.

- $\quad$ As conclusões a que se chega abdutivamente não têm caráter mandatório, valendo apenas como um conhecimento hipotético embora plausível; à diferença do conhecimento proporcionado pela dedução, esse é contudo um conhecimento novo: a abdução é sempre uma forma de fazer a pergunta que conta, a que leva verdadeiramente ao desvendamento do mistério, à descoberta.

Quando se considera o caráter problematológico, narrativo e de desvendamento que Peirce atribui à abdução, não causa surpresa constatar que autores como Umberto Eco, Thomas A.Sebeok e Jaakko Hintikka tenham apontado como protótipo do raciocínio abdutivo a personagem literária de Sherlock Holmes. No método de Sherlock Holmes confluem, na verdade, dois hábitos distintos: a observação minuciosa e a capacidade de integrar os detalhes numa explicação única, altamente coerente e verossímil. Desses dois hábitos, apenas o segundo é autenticamente abdutivo, mas não admira que ele tenha impressionado tanto àqueles autores: afinal, é a capacidade de dar coerência às informações parcialmente contraditórias da observação que dá às soluções de Sherlock Holmes seu caráter simultaneamente surpreendente e incontestável. 


\section{ORIENTAÇÕES}

Ao longo deste escrito, procurei elaborar o contraste entre semântica e pragmática ou, melhor dizendo, procurei definir essas duas noções de modo a torná-las compatíveis com o modo como tenho usado os dois termos. Entendendo que ambas as disciplinas dizem respeito à competência para interpretar que caracteriza os falantes de uma língua, mas se referem a processos interpretativos qualitativamente diferentes, procurei dar exemplos de ambos os processos. Com isso, acabei desqualificando, como bons exemplos de fenômenos pragmáticos a dêixis, os atos de fala e a pressuposição, ao passo que retive as implicaturas conversacionais, tomando-as como protótipo do fazer pragmático.

Tenho consciência de que minha escolha pode surpreender, pois ela se contrapõe a outras maneiras de separar os dois campos que são (ou pelo menos já foram) bastante consensuais. Muitos autores, até hoje, fazem coincidir o limite entre semântica e pragmática com o limite entre as informações que uma expressão fornece enquanto tipo e as informações que fornece enquanto ocorrência ou uso. Essa distinção levou a apontar como protótipo da interpretação pragmática o processo pelo qual definimos numa dada situação de fala a referência dos dêiticos ou o processo pelo qual determinamos se uma sentença, contendo pressupostos, poderá receber um valor de verdade num contexto dado. Para outros autores, o limite entre semântica e pragmática pareceu coincidir com a distinção entre os conteúdos que se explicam por uma concepção estritamente representacional das funções da linguagem, e aqueles que só se explicam por uma concepção interacional. Em oposição a essas definições que são consensuais em alguns grupos de pesquisa, eu defini a semântica e a pragmática como disciplinas que tratam, respectivamente, de aspectos da interpretação que são em princípio calculáveis, e de apectos não-redutíveis a um cálculo. Por esse critério, o lingüista teria que encarar de maneiras diferentes os dêiticos, as pressuposições e os valores ilocucionários, que têm interpretações previsíveis a partir do léxico e das construções gramaticais, e as implicaturas, essencialmente imprevisíveis. 
É natural perguntar se essa distinção é interessante; poderia com efeito parecer 1) que ela produz um forte esvaziamento da pragmática, já que 2) alguns dos temas mais tradicionais dessa disciplina ficariam "desclassificados" como semânticos, com base num critério que pode parecer obscuro a muitos. Consideremos mais atentamente essas duas objeções.

Consideremos primeiro o que chamei de "desclassificação". Evidentemente, dizer que um fenômeno foi desclassificado porque foi tratado como semântico não pode ser uma atitude científica. Penso que a preocupação de alguns de nossos lingüistas em querer qualificar como pragmática sua própria atividade científica reflete a atitude, própria de um ambiente científico que foi por muito tempo dependente de importações externas, para procurar praticar as disciplinas mais "modernas" ou mais "avançadas", e para qualificar o próprio trabalho como correspondendo a essas disciplinas. Essa atitude não garante análises mais adequadas, e é na verdade responsável por um grande número de incursões que ignoram as anteriores, e que deixam às vezes alguns caminhos apontados, mas não resultam numa descrição sistemática da língua. No tocante à pragmática, ela resultou em banalizar o uso do termo que, tendo sido freqüentemente empregado apenas por suas conotações, perdeu a capacidade de indicar um limite.

A meu ver, esse limite é o que conta acima dos rótulos. Ele precisa ser preservado, na medida em que isso ainda é possível, bastando para tanto que se sigam duas recomendações simples: a) evitar o uso de métodos pragmáticos quando os métodos semânticos bastam; b) decidir se um problema é semântico ou pragmático não com base nas próprias preferências teóricas ou na representação que fazemos de nós mesmos como cientistas "atualizados", mas nas categorias de que se lançou mão para sua solução.

Apenas para esclarecer a última dessas "recomendações simples", lembro que, há alguns anos, o Prof. Kanavillil Rajagopalan e eu nos envolvemos inesperadamente numa polêmica que, graças sobretudo ao bom humor e ao gosto daquele colega pelo debate, 
acabou sendo muito agradável para ambos, além de instrutiva. A polêmica era a propósito de diálogos como este, que eu havia tratado em ILARI (1983):

(45) A - Soube que você trabalha na mesma sala que o Paulo.

B - Não sou eu que trabalho na mesma sala que o Paulo, o Paulo é que trabalha na mesma sala que eu.

O motivo de discórdia era a natureza da negação que ocorre na fala do interlocutor B, para a qual o Prof. Rajan preconizava a necessidade de uma explicação pragmática, ao passo que eu queria explicála semanticamente, mesmo que não dispusesse de uma explicação convincente. ${ }^{24}$ Mantenho a posição que então defendi: não adianta tratar o não dessa fala como uma negação pragmática se, ao fim e ao cabo, a regra que o explica é a velha regra semântica que se aplica aos outros tipos mais corriqueiros de não, e fala em inversão dos valores de verdade.

Poder-se-ia contestar a maneira como propus distinguir semântica e pragmática afirmando que a prova cabal para dizer que algo é ou não é calculável consiste, afinal, em dispor de uma fórmula de cálculo convincente, e lembrando que a evolução histórica do quadro de fenômenos considerados calculáveis foi impressionante. Evidentemente, minha tentativa de definição pressupõe a existência de aspectos da interpretação que não só não foram nunca calculados, mas que são, não calculáveis por princípio - o que é uma outra maneira de distinguir processos interpretativos dedutivos e abdutivos. $\mathrm{Na}$ realidade, encontrar ou não um método de cálculo adequado a um fenômeno de interpretação corresponde a um segundo momento, teórico, de apreensão do fenômeno. No primeiro momento, que é ainda pré-teórico e intuitivo, basta perceber que o processo interpretativo em questão é sistemático, que seus resultados são inteiramente previsíveis, que ele pode ser reduzido a algum tipo de cálculo. Salvo engano meu, essas intuições são intersubjetivas e confiáveis. ${ }^{25}$

Respondendo à outra objeção, e corrigindo a impressão de esvaziamento, quero deixar claro que a lista de fenômenos pragmá- 
ticos que "sobram" uma vez adotadas as definições aqui propostas, é enorme. Os fenômenos que reunimos sob a denominação comum de "implicaturas conversacionais" são extremamente variados, merecendo um estudo tipológico alentado; como o próprio Grice já tinha observado, várias figuras retóricas explicam-se como implicaturas, o que já abre um enorme campo de investigações. Mas o elemento problematológico e narratológico que distingue a interpretação pragmática está igualmente presente numa série de fenômenos em que as informações insuficientemente exatas da linguagem precisam fazer sentido num contexto de fala mais amplo. Não estou, evidentemente, me referindo à dêixis, mas à vagueza: os estudos sobre vagueza mostram que, além de uma vagueza de tipo escalar, apontada por BIERWISCH (1969) em adjetivos como velho, quente, alto, etc., os falantes mantêm absoluto controle sobre outro tipo de vagueza, a criterial, que se manifesta, por exemplo, em adjetivos como inteligente. Decidir que tipo de inteligência é apropriado para uma determinada situação implica em reencontrar uma coerência, avaliando relevâncias pelo procedimento narratológico que atribui à pragmática.

Lembro ainda que a maioria dos operadores argumentativos apontam para operações de completamento que terão que ser realizadas com os elementos do contexto, num jogo "sem cartas marcadas". Assim, o uso adequado da expressão até mesmo informa o interlocutor-intérprete de que deve referir-se a uma escala argumentativa; qual seja exatamente essa escala é normalmente o problema que o interlocutor-intérprete terá que enfrentar e resolver. Novamente, temos aqui um working-out pragmático. Alguém poderia sentir-se incomodado porque, nos últimos fatos aqui mencionados, algo calculável e algo incalculável aparecem como parte de uma mesma palavra ou expressão. Não há nisso nenhum problema para quem esteja disposto a admitir que a linguagem é (sempre, parcialmente) indeterminada, e na verdade todas as ações pragmáticas (no sentido aqui definido) administram essa indeterminação.

Assim, embora traçar o limite entre o calculável e o incalculável, no interior de uma mesma costrução ou palavra, seja geralmente um 
problema delicado, esse problema aponta para um aspecto fundamental da linguagem humana. Como argumento a favor da distinção que procurei traçar neste escrito, vale a observação de que, sem ela, esse problema não poderia nem sequer ser formulado.

\section{NOTAS}

${ }^{1}$ Os autores e escolas historicamente importantes que o texto não considera são inúmeros. Sobre alguns deles escrevi em outros lugares (vejam-se, entre outros, ILARI (1981), (1985), (1992), (1996)).

${ }^{2}$ Para o leitor interessado nesse tipo de introdução, pode ainda ser útil a leitura da Semântica de Ilari e Geraldi, publicado como vol. 8 da coleção Princípios pela Editora Ática, de São Paulo (1ª edição, 1985. 10ª edição: 1999).

${ }^{3}$ Um exemplo conhecido dos lingüistas brasileiros é o de DUCROT (1972) que, embora caracterize o pressuposto como uma propriedade semântica de certas palavras ou construções, e trate portanto dos pressupostos no nível que Morris caracterizaria como "semântico", também entende que o pressuposto representa um certo tipo de ação verbal do locutor, e por isso "invade" a pragmática. Na leitura que por muito tempo pareceu apropriada para aquele texto de Ducrot, as expressões introdutoras de pressuposição denotam, por assim dizer, uma certa ação verbal que os interlocutores realizam, o que representa uma subversão da hierarquia de Morris.

${ }^{4}$ Ver ILARI, a sair.

${ }^{5}$ A consulta de livros de linguística pode ser vantajosa, neste caso, porque nem sempre os manuais de lógica expõem em detalhe a semântica dos quantificadores. Para a discussão que estou fazendo aqui, são referências úteis, entre tantas outras, ALLWOOD et al. (1977), p. 58-95; DOWTY et al. (1983), cap. 3; CHIERCHIA \& MC CONNELL-GINET (1993) cap. 3; ILARI (1986), cap. 4).

${ }^{6}$ Lembre-se que isso é necessário na perspectiva de Tarski, sob pena de perder o apoio da sintaxe na construção de uma semântica para uma língua infinita.

${ }^{7}$ Para um balanço exigente embora informal das orientações trilhadas por esse tipo de semântica, veja-se E. BACH (1987).

${ }^{8}$ Para distinguir intensões e extensões, ainda vale a discussão em FREGE (1892). Frege distinguiu aí Bedeutung (" extensão, referência) e Sinn (" intensão, sentido) e mostrou que essas duas dimensões semânticas se aplicam a expressões lingüísticas de diferentes categorias sintáticas. Pode ser útil lembrar que, na tradição fregeana de análise da língua, os nomes, os predicados e as orações têm como referência ou extensão, respectivamente, objetos, conjuntos de objetos e 
valores de verdade; e que os sentidos ou intensões dos nomes, predicados e orações são respectivamente modos de apresentação dos referentes, propriedades e proposições.

${ }^{9}$ Quine sobre as intensões, ver QUINE (1963), cap. 4.

${ }^{10}$ Ver PLATTS (1979).

${ }^{11}$ Minha idéia é que uma semântica formal dá conta do sentido literal quando ele é composicional. Sobre composicionalidade, falo em outro texto desta coletânea.

${ }^{12}$ Diante de uma sentença como "Maria é um doce", Davidson diria que "Maria" e "doce" têm seu sentido e referência habituais, e que portanto a frase como um todo é um contrassenso ou uma evidente falsidade. Isso não resulta de desconhecer que a sentença tenha um significado segundo, não literal, mas precisamente de reconher que, até onde se pode aplicar à sentença um manual "semântico" de tradução, o que se obtém é aquele contrassenso.

13 Ver mais comentários sobre esse e outros exemplos na resenha do texto de Lemos por ILARI et al. (1990).

${ }^{14}$ Essa crítica visa especificamente o modo como os dêiticos são tratados na General Semantics de Lewis e no programa de análise semântica das línguas naturais de Richard Montague.

${ }^{15} \mathrm{Na}$ realidade, Stalnaker vai bem mais longe do que estou sugerindo, pois refere às duas formas de interpretação que ele distingue - a que se baseia nos contextos, por dêixis, e a que resulta dos estados de coisas, via mundos possíveis - a conhecida ambigüidade entre uma interpretação "referencial" e uma interpretação "atributiva" das descrições definidas, apontada em DONNELLAN (1966) a propósito do exemplo "Smith murderer is insane"

${ }^{16}$ A Lógica de Port-Royal, em seu capítulo sobre os "exponíveis", pode ser considerada uma primeira tentativa de repertoriar exaustivamente as construções gramaticais que introduzem pressuposições na sentença, e suas descrições continuam em grande parte válidas. A preocupação de repertoriar as construções introdutoras de pressuposições e de classificá-las para diferentes propósitos está igualmente presente em vários trabalhos contemporâneos, entre os quais assinalo um texto pouco conhecido de Keenan.

${ }^{17}$ Essa análise é feita na última parte daquele célebre artigo, em que Frege, tendo já consolidado a tese de que a referência de uma oração declarativa completa é seu valor de verdade, está interessado em verificar se os valores de verdade das orações subordinadas afetam o valor de verdade do período de que fazem parte. Contrariamente à análise gramatical que faríamos, "Quem descobriu a forma elíptica da órbita dos planetas" é descrita por Frege como uma oração subordinada substantiva, o que explica que ela possa ser tratada a essa altura de sua exposição. 
${ }^{18}$ Para um balanço abrangente das expressões que introduzem pressuposição em português recomenda-se a leitura da dissertação de mestrado de Heberth Paulo de Souza, A pressuposição em português, defendida na Pontifícia Universidade Católica de Minas Gerais em janeiro de 2000.

${ }^{19}$ GRICE (1975: 43). Utilizei a tradução brasileira de J.W. Geraldi que consta em DASCAL (1982).

${ }^{20}$ A noção de atividade de coordenação foi elaborada por LEWIS (1972). Intuitivamente, há uma atividade de coordenação toda vez que dois indivíduos têm que encaminhar uma decisão antecipando a possível decisão do outro. Suponha-se o caso em que A marcou encontro com B no escritório de um advogado famoso, que fica tradicionalmente numa certa rua do centro da cidade, e ao chegar a esse lugar encontra um aviso de que o escritório em questão se mudou há algum tempo. A atividade de coordenação começa quando A se pergunta se B virá para o endereço antigo ou irá par o endereço novo, levando ademais em conta que a decisão de B sobre onde ir poderia ser influenciada por aquilo que ele, A, venha a fazer, etc. Ver também BENNETT (1976).

${ }^{21}$ A idéia de separar a semântica e a pragmática como os domínios do calculável e do não-calculável resulta de um comentário feito pelo Prof. Luiz Henrique Lopes dos Santos, durante uma discussão do texto "Pragmatics", de Stalnaker, durante uma reunião na década de 70. A discussão em questão aconteceu num dos seminários sobre lógica e linguagem que então funcionavam na Pós-Graduação em Lingüística do Instituto de Estudos da Linguagem da UNICAMP, em paralelo às disciplinas lingüísticas da área de Semântica.

${ }^{22}$ Por exemplo: embora seja intuitivamente válido deduzir que (1) "Maria é mãe de Deus" das premissas (2) "Maria é mãe de Jesus" e (3) "Jesus é Deus", essa dedução não podia ser representada formalmente em sua lógica, pois nessa lógica Jesus não é um termo na segunda premissa.

${ }^{23}$ Parret analisa estes fragmentos de Peirce, relevantes para o tema aqui tratado: 1.139, 1.630, 2.120, 2.192, 2.442, 2.634, 2.776, 2.786, 2.754, 3.362, 5.35, 5.111, $5.157,5.171,5.181,5.188,5.189,5.196,5.197,5.400,6.416,6.475-77,7.36,7.48$, 7.220, 7.232, 7.255 .

${ }^{24}$ Alguns dos escritos que compõem essa polêmica foram retomados no $n^{\mathrm{o}} 13$ dos Cadernos de Estudos Lingüísticos.

${ }^{25}$ A história da semântica e seu desenvolvimento mais recente mostram que os grandes semanticistas foram guiados por intuições bastante seguras a respeito do que poderia ser ou não objeto de um cálculo. 


\section{REFERÊNCIAS BIBLIOGRÁFICAS}

ALLWOOD, J. et al. Logic in Linguistics. Cambridge: Cambridge U.P., 1977.

APEL, K.O. Peirce: from pragmatism to pragmaticism. Amherst: University of Massachussets Press, 1981.

ARNHEIM, R. Visual thinking. Berkeley: University of California Press, 1969.

AUSTIN, J. L. Performative-constative. In: CATON, Ch.E. (Org.). Philosophy and ordinary language. Urbana: University of Illinois Press, 1963. p.22-54.

AUSTIN, J. L. How to do things with words. Oxford: Oxford U.P., 1962.

BACH, E. Informal lectures on formal Semantics. New York: State University of New York Press, 1987.

BENNETT, J. Linguistic behaviour. Cambridge: Cambridge U.P., 1976.

BIERWISCH, M. On classifiying semantic features. In: BIERWISCH, HEIDOLPH

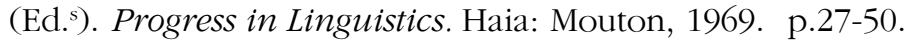

CHIERCHIA, G., MCCONNELL-GINET, C. Meaning and grammar an introduction to Semantics. Cambridge: MIT Press, 1993.

CROCE, B. Breviario di Estetica. Bari: Laterza, 1914.

CROCE, B. Aesthetica in nuce. Bari: Laterza, 1928.

DANES, F. A three level approach to syntax.Travaux Linguistiques de Prague, 1, p. 225-240, 1966.

DAVIDSON, D. (1967a) Truth and meaning. Synthese VIII (1967), p.304-323. (Trad. brasileira R.Ilari in: DASCAL (Org.). Fundamentos metodológicos da Lingüística. Campinas: Edição do Organizador, 1982, p.143-179.

DAVIDSON, D. The logical form of action sentences. In: RESCHER, N. (Ed.) The logic of decision and action, 1967b. Reimpresso com comentários de vários autores em DAVIDSON, D. Essays on actions and events. Oxford: Clarendon, 1980, p.105-148.

DAVIDSON, D. On saying that. In: DAVIDSON, D., HINTTIKA, J. Words and objections. Dordrecht: Reidel, 1969. p.158-174.

DAVIDSON, D. What metaphors mean, 1978. Republicado em Inquiries into truth and interpretation. Oxford: Clarendon, 1984. p.245-264.

DONNELLAN, K. S. Reference and definite descriptions. The Philosophical Review, LXXV, 3, p.281-304, 1966. (Reimpresso em ROSENBERG, J.F. \& TRAVIS, Ch. (Org. ${ }^{\text {) }}$ Readings in the Philosophy of Language. Englewood Cliffs: Prentice Hall, 1971, p.196-211.

DOWTY, D. Word meaning and Montague Semantics. Dordrecht: Reidel, 1979. 
DOWTY, D., WALLS, P., PETERS, S. Introduction to Montague Semantics. Dordrecht: Reidel, 1983.

DUCROT, O. Dire et ne pas dire, principes de Sémantique linguistique. Paris: Hermann, 1972.

ECO, U. Il segno dei tre. Holmes, Dupin, Peirce. Milão: Bompiani, 1983.

FILLMORE, Ch. Types of lexical information. In: KIEFER, F. (Ed.). Studies in Syntax and Semantics. Dordrecht: Reidel, 1969. p.109-136.

FREGE, G. Über Sinn und Bedeutung. In: Zeitschrift für Philosophie und philosophische Kritik, NF 100, 1892. p.15-50. [Tradução brasileira de Paulo Alcoforado Sobre sentido e referência. In: FREGE. Lógica e Filosofia da Linguagem. São Paulo: Cultrix /EDUSP, 1878, p.59-85]

GERALDI, J. W. Se a Semântica fosse também pragmática ou para uma análise dos enunciados condicionais. Campinas: Instituto de Estudos da Linguagem da Unicamp, 1978. ( Dissertação de Mestrado)

GOODMAN, N. Language of art: an approach to a theory of symbols. New York: Bobbs-Merrill, 1968.

GREIMAS, A. J. Du sens. Paris: Seuil, 1970.

GRICE, H.P. Conversational relevance. In: COLE, MORGAN. Syntax and Semantics, v.3. New York: Academic Press, 1975. p.41-58. [ Tradução brasileira de João Wanderley Geraldi em DASCAL, M. (Org.) Fundamentos Metodológicos da Linguística, v. 4. = Pragmática. Problemas, Críticas, Perspectivas da Linguística. Campinas: Ed. do Organizador, 1982. p.81-103 ]

HARMAN, G. Threee levels of meaning. In: STEINBERG, JAKOBOVITZ. Semantics. Cambridge: Cambridge U.P., 1968. p. 66-75

ILARI, R. Os reflexivos e a interpretação dos prossintagmas verbais. Cadernos de Estudos Lingüisticos, 2, p.56-157, 1981.

ILARI, R. Dois problemas de imperfeita simetria. Ensaios de Linguística, 9, p.104-120, 1983.

ILARI, R. A Semântica interpretativa em sua fase mais antiga: uma leitura de Structure of a semantic theory". Cadernos de Estudos Linguísticos, 8, p.43-66, 1985.

ILARI, R. O que fazer quando '2+3' não é igual a '3+2': a semântica e a pragmática das construções simétricas em língua natural. Cadernos de Estudos Linguísticos, 13, p.97-103, 1987.

ILARI, R. Perspectiva funcional da frase portuguesa. 2.ed. Campinas: Edunicamp, 1992.

ILARI, R. Estruturalismo e Semântica. MARI, Hugo et alii: Estruturalismo, memória e repercussões. Rio de Janeiro: Diadorim, 1996. p. 95-116. 
ILARI, R. Semântica e representação do sentido. (Ms. Campinas: Unicamp.) (No prelo)

ILARI, R., GODOI, H. e OLIVEIRA, R. Pires de. Resenha a LEMOS, C.T. "Ser" and "estar" in Brazilian Portuguese, with particular reference to child language acquisition. (Tuebingen: G.Narr, 1990), 1985.

KARTTUNEN, L. Presuppositions of compoud sentences. Linguistic Inquiry, IV, p.169-195, 1971.

LEMOS, C.T. de. "Ser" and "estar" in Brazilian Portuguese, with particular reference to child language acquisition. Tübingen: Günter Narr, 1985.

LEWIS, D. General Semantics. In: DAVIDSON, D., HARMAN, G. Semantics of natural languages. Dordrecht: Reidel, 1972a. p. 169-218.

LEWIS, D. Convention, a philosophical study, 1972b. [Tradução italiana de Gabriele Usberti: La Convenzione. Milão: Bompiani, 1974]

MONTAGUE, R. The proper treatment of quantification in English. In: THOMASON, R. (Ed.) Formal Philosophy. Nova York e Londres: Yale U.P.

MORRIS, Ch. Signs, language and behaviour, 1933. [tradução italiana de Silvio Ceccato, Segni, Linguaggio, Comportamento. Milão: Longanesi, 1963]

PARRET, H. (1993). The aesthetics of communication, pragmatics and beyond. DORDRECHT, Kluwer. [Trad. brasileira de Roberta Pires de Oliveira: A estética da comunicação. Campinas: Edunicamp, 1996]

PEIRCE, Ch. S. Collected papers. Cambridge: Harvard U.P.

PEIRCE, Ch. S. Philosophical writings of Peirce. Selected and edited with an introduction by Justus Buchler. N.York: Dover, 1955.

PEIRCE, Ch. S. Semiótica e Filosofia, textos escolbidos de Charles Sanders Peirce. Introdução e tradução de OCTANNY, S. da Mota e HEGENBERG, L. S.Paulo: Cultrix, 1972.

PLATTS, M. Ways of meaning. Londres: Routledge and Kegan Paul, 1979.

QUINE, W.v.O. Word and object. Cambridge: MIT Press, 1963.

RAJAGOPALAN, K. Quando "2+3" não é igual a "3+2": a semântica e a pragmática das construções simétricas em língua natural. Cadernos de Estudos Linguísticos, 13, p. 67-95, 1987.

RUSSELL, B. On denoting. Logic and knowledge. Londres: Allen \& Unwin, 1905. p. 39-56. Reimpresso em Zabeeh, Klemke \& Jacobson (Ed.s) Readings in Semantics. University of Illinois Press, 1974. p.141-158.

STALNAKER, R. Pragmatics. In: DAVIDSON, D., HARMAN, G. Semantics of natural languages. Dordrecht: Reidel, 1972. p.380-397. 
STRAWSON, P. F. On referring. In: Flew, A. (Ed.) Essays on conceptual analysis. Houndmills Basingstoke Hampshire: Macmillan, 1956. Reimpresso em ZABEEH, KLEMKE, JACOBSON (Ed.s). 1974. p.159-192.

TARSKI, A. The semantic conception of truth. Philosophy and phenomenological research, IV, 3, p.341-375, 1944). Reimpresso em ZABEEH, KLEMKE, JACOBSON (Ed.s), 1974, p.675-712.

WEINREICH, U. On the semantic structure of language. In: GREENBERG, J. (Ed.) Universals of Language. 2nd ed. Cambridge: MIT Press, 1963. p.142215.

ZABEEH, KLEMKE, JACOBSON (Ed.'). Readings in Semantics. University of Illinois Press, 1974.

VOGT, C.A. A palavra envolvente. São Paulo: Ática, 1976. 